\title{
Macrofossils in Raraku Lake (Easter Island) integrated with sedimentary and geochemical records: towards a palaeoecological synthesis for the last 34,000 years
}

\author{
N. Cañellas-Boltà a,b,*, V. Rull ${ }^{\text {a }}$, A. Sáez ${ }^{\text {b }}$, O. Margalef ${ }^{c}$, S. Giralt ${ }^{c}$, J.J. Pueyo ${ }^{\text {d }}$, H.H. Birks ${ }^{\text {e,f }}$, \\ H.J.B. Birks ${ }^{\text {e,f,g, h, S. Pla-Rabes }}{ }^{i}$ \\ ${ }^{a}$ Laboratory of Palynology and Paleoecology, Botanic Institute of Barcelona (IBB-CSIC-ICUB), Passeig del Migdia s/n, E-08038 Barcelona, Spain \\ ${ }^{\mathrm{b}}$ Department of Stratigraphy, Paleontology and Marine Geosciences, Universitat de Barcelona, Martí Franquès s/n, E-08028 Barcelona, Spain \\ ' Institute of Earth Sciences Jaume Almera (ICTJA-CSIC), Lluís Solé Sabarís s/n, E-08028 Barcelona, Spain \\ ${ }^{\mathrm{d}}$ Department of Geochemistry, Petrology and Geological Prospecting, Universitat de Barcelona, Martí Franquès s/n, E-08028 Barcelona, Spain \\ e Department of Biology, University of Bergen, Post Box 7803, N-5020 Bergen, Norway \\ ${ }^{\mathrm{f}}$ Bjerknes Centre for Climate Research, Post Box 7810, NO-5020 Bergen, Norway \\ ${ }^{\mathrm{g}}$ Environmental Change Research Centre, University College London, London, WC1E 6BT, UK \\ h School of Geography and the Environment, Oxford University, Oxford, OX1 3QY, UK \\ ${ }^{\mathrm{i}}$ Center for Advanced Studies of Blanes (CEAB-CSIC), Accés Cala St. Francesc 14, E-17300 Blanes, Spain
}

\section{A R T I C L E I N F O}

\section{Article history:}

Received 29 June 2011

Received in revised form

13 December 2011

Accepted 14 December 2011

Available online 24 January 2012

\section{Keywords:}

Rapa Nui

Palaeolimnology

Taphonomy

Macrofossils

Geochemistry

Sedimentary facies

Last glacial period

Holocene

\begin{abstract}
A B S T R A C T
Macrofossil analysis of a composite $19 \mathrm{~m}$ long sediment core from Rano Raraku Lake (Easter Island) was related to litho-sedimentary and geochemical features of the sediment. Strong stratigraphical patterns are shown by indirect gradient analyses of the data. The good correspondence between the stratigraphical patterns derived from macrofossil (Correspondence Analysis) and sedimentary and geochemical data (Principal Component Analysis) shows that macrofossil associations provide sound palaeolimnological information in conjunction with sedimentary data. The main taphonomic factors influencing the macrofossil assemblages are run-off from the catchment, the littoral plant belt, and the depositional environment within the basin. Five main stages during the last 34,000 calibrated years BP (cal yr BP) are characterised from the lithological, geochemical, and macrofossil data. From 34 to $14.6 \mathrm{cal}$ kyr BP (last glacial period) the sediments were largely derived from the catchment, indicating a high energy lake environment with much erosion and run-off bringing abundant plant trichomes, lichens, and mosses into the centre of Raraku Lake. During the early Holocene the infilling of the lake basin and warmer conditions favoured the growth of a littoral plant belt that obstructed terrigenous input. Cladoceran remains and Solanaceae seeds are indicative of reduced run-off and higher values of $\mathrm{N}$ and organic $C$ indicate increased aquatic and catchment productivity. From 8.7 to 4.5 cal kyr BP a swamp occupied the entire basin. The increase of Cyperaceae seeds reflects this swamp development and, with oribatid mites and coleopteran remains, indicates a peaty environment and more anoxic conditions in Raraku. At around 4.5 cal kyr BP dry conditions prevented peat growth and there is a sedimentary hiatus. About 800 cal yr BP, peat deposition resumed. Finally, in the last few centuries, a small lake formed within the surrounding swamp. Evidence of human activity is recorded in these uppermost sediments.

(c) 2011 Elsevier Ltd. All rights reserved.
\end{abstract}

\section{Introduction}

Lakes are natural sediment traps and preserve an archive of the history of the past ecosystems (Smol and Glew, 1992; Battarbee,

\footnotetext{
* Corresponding author. Department of Stratigraphy, Paleontology and Marine Geoscience, Universitat de Barcelona, Martí Franquès s/n, E-08028 Barcelona, Spain. Tel.: +34 932890611, +34 934034489; fax: +34 932890614, +34934021340.

E-mail address: nuriacatcb@gmail.com (N. Cañellas-Boltà).
}

2000; Cohen, 2003). Proxy data for the physical, chemical, and biotic composition of the lake and its water can be retrieved from lake sediments and used to provide information about environmental and biotic changes that have occurred over time. Many factors influence the proxy record, such as temperature, precipitation, terrestrial and aquatic biota, human activities, lake-bottom topography, depth, hydrological regime, size and composition of the catchment and other environmental parameters together with their corresponding interactions (Smol and Glew, 1992; Battarbee, 
2000; Birks et al., 2000; Fritz, 2008; Giralt et al., 2008). A lake is integrated with its catchment and geological processes such as weathering, run-off, and deposition can play an important role in influencing the sediment composition (Tschudy, 1969; Birks et al., 2000; Cohen, 2003; Lotter and Birks, 2003). Processes such as bioturbation and diagenesis can modify lacustrine sediments.

Many recent palaeolimnological studies have been directed at reconstructing external environmental variables such as climate, rather than being interested in the lake's history for its own sake (Cohen, 2003; Anderson et al., 2008). However, the lake itself interposes an important filter between our reconstruction of the past external environment and the sedimentary record we use to derive this reconstruction (Cohen, 2003). Understanding the sedimentary evolution of the lake basin is therefore essential in palaeolimnological studies, because it determines the nature of the palaeolimnological record and our ability to infer environmental changes from it.

Macrofossils are one of the most useful biological proxies in palaeoecological studies because they reflect local biota and ecosystems and hence local environmental conditions (Birks and Birks, 2000; Birks, 2007). Macrofossil studies have been developed mainly in Europe and North America in temperate and arctic areas. Plant macrofossils are most frequently used, although other organisms, particularly invertebrates such as coleoptera, chironomids, oribatids, cladocerans, etc. also give useful palaeoecological and palaeoenvironmental information (Birks et al., 2000).

The main within-basin processes that influence the sedimentary patterns of macrofossils are transportation, sorting, redeposition, decomposition, and reworking (Tschudy, 1969; Scheihing and Pfefferkorn, 1984; Birks, 2001; Cohen, 2003). A sound interpretation of fossil evidence cannot be made without considering the influence of these taphonomic processes which act on the chemical and physical attributes of the sediments and the fossils themselves (Tschudy, 1969; Rubensdotter and Rosqvist, 2003). Many studies have shown the importance of taphonomy in the interpretation of a macrofossil record, mainly by the use of modern sediment samples (see review by Dieffenbacher-Krall, 2007).

Palaeoecological research on Rano Raraku and Easter Island has largely involved palynological studies (see studies of Flenley and King, 1984; Flenley et al., 1991; Dumont et al., 1998; Butler et al., 2004; Azizi and Flenley, 2008; Mann et al., 2008; among others). A few studies include macroremains, such as the palaeoecological work of Dumont et al. (1998) and Mann et al. (2008) on Raraku Lake, the study of Peteet et al. (2003) on Rano Aroi, and archaeological work on the island (Orliac and Orliac, 1998; Orliac, 2000; Horrocks and Wozniak, 2008). This paper presents a macrofossil analysis of the glacial to Holocene lake sediments (34,000 calibrated years BP -cal yr BP-) of Rano Raraku and relates the results to previous lithological, sedimentological, and geochemical analyses (Sáez et al., 2009), in order to determine the influence of sedimentological processes on the macrofossil assemblages and the relationship between biological remains and geochemical parameters. The main aim is to improve our knowledge of the palaeolimnology of Rano Raraku and the palaeoenvironment of Easter Island.

\section{Study site}

Easter Island is a tiny $\left(164 \mathrm{~km}^{2}\right)$ volcanic island situated in the southern Pacific Ocean $\left(27^{\circ} 07^{\prime} \mathrm{S}, 109^{\circ} 22^{\prime} \mathrm{W}\right.$ ) (Fig. 1). It is one of the most isolated places on Earth, about $3700 \mathrm{~km}$ from the Chilean coast and $2030 \mathrm{~km}$ from the nearest inhabited island (Pitcairn). The climate is subtropical, with an average annual temperature of $21^{\circ} \mathrm{C}$ and a range of average monthly temperatures between $18{ }^{\circ} \mathrm{C}$ in August and $24^{\circ} \mathrm{C}$ in January (Mann et al., 2008). The total annual precipitation is highly variable, ranging between 500 and $2000 \mathrm{~mm}$, with large alternating dry and humid periods (Horrocks and Wozniak, 2008). The island's topography is characterised by volcanic cones and the rolling surfaces of the lava flows between them. The highest point is the summit of the Terevaka volcano $(511 \mathrm{~m})$. No permanent surface streams are present due to the high permeability of the volcanic rocks (Herrera and Custodio, 2008). At present, only the craters of Rano Raraku and Rano Kau (occupied by lakes), and Rano Aroi (filled by a swamp) permanently contain freshwater. The floral and faunal diversity have been described as very poor (Skottsberg, 1956; Zizka, 1991). Nowadays the island is mostly (90\%) covered by meadows dominated by grasses, with a few tree plantations, shrub areas, and pioneer vegetation (Etienne et al., 1982).

Raraku Lake is a small $\left(0.11 \mathrm{~km}^{2}\right)$ shallow (2-3 m depth) freshwater lake, situated at $75 \mathrm{~m}$ altitude inside a volcanic crater more than 300,000 years old (Baker et al., 1974) (Fig. 1). The crater is famous as the quarry of the moais, the gigantic stone sculptures erected by a vanished civilization. The catchment area is about $0.35 \mathrm{~km}^{2}$ and it is composed of volcanic tuff rich in glass, feldspar, and ilmenite (González-Ferran et al., 2004). The lake is hydrologically closed and disconnected from the island's main groundwater by impermeable lacustrine sediments, being fed solely by precipitation in the crater (Herrera and Custodio, 2008). The lake water is well mixed, acidic ( $\mathrm{pH}$ around 6.3), dilute (average specific conductivity is $640 \mathrm{mS} \mathrm{cm}{ }^{-1}$, Geller, 1992) and of a $\mathrm{Cl}-\mathrm{HCO}_{3}-\mathrm{Na}$ type (Sáez et al., 2009). Today the lake bottom is flat and it is surrounded by a littoral belt formed mainly by a mat of Scirpus californicus, which also forms large floating patches. In recent years water has been episodically siphoned out the lake for human consumption and irrigation.

The lithology and main characteristics of the sedimentary infill of Lake Raraku were characterised from eight sediment cores recovered in 2006 (Fig. 2). The nine sedimentary facies described by Sáez et al. (2009) have been generalised here to four major sedimentary facies (Table 1 ). The lowest facies consists of dark grey-reddish organic-rich muddy silt laminated by water currents, including frequent turbidite episodes. It is interpreted as a being derived largely from the steep catchment slopes by water transport and slope-wash, and is termed the High Gradient Lake facies (HGL). It has the lowest organic content (60\% of dry weight) and the largest mineral fraction of the sequence which consists of volcanic minerals (glass, feldspar, and iron oxide), clay minerals, and pyrite aggregates (Sáez et al., 2009). The overlying facies consists of horizontally coloured laminated algal and organic brown banded mud, including rare turbidite episodes, and massive brownish organic mud, all consisting mostly of nonparticulate, amorphous organic matter. It is interpreted as being derived from less steep lake-bottom slopes and autochthonous production with little input from the catchment. It is termed the Low Gradient Lake facies (LGL). The sediment above is composed of reddish-brown massive or banded muddy peat, composed mainly of macroremains of sedges (Scirpus and Cyperus spp.). It is termed the Swamp facies association (SWA). A transitional facies between the LGL and the SWA, composed of organic mud rich in macroremains of sedges, has also been recognised. At the top, a silica-rich silty peat represents shallow water surrounded by floating peat (LFP, Low Gradient Lake with Floating Peat facies).

\section{Methods}

Core RAR 03 and the lower part of core RAR 07 (Fig. 2) were combined into a complete and continuous stratigraphic section $19 \mathrm{~m}$ long. Fifty-six samples for plant macrofossil analysis were 


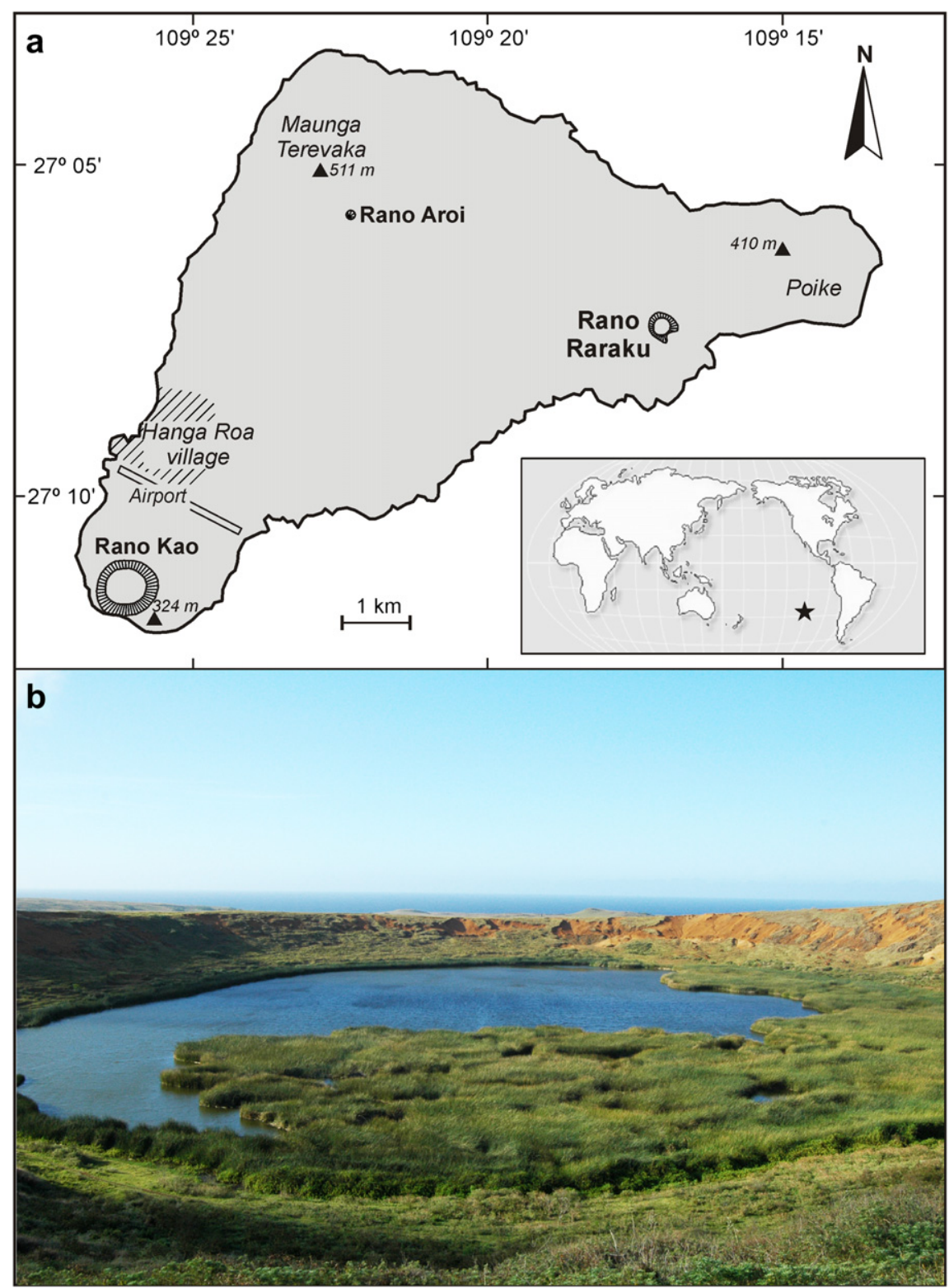

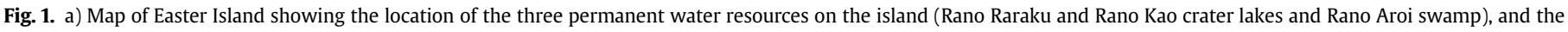
location of the island in the SE Pacific Ocean. b) Picture of Rano Raraku, a crater lake.

extracted and processed following standard protocols (Birks, 2001). Sample volume, between 20 and $50 \mathrm{~cm}^{3}$, was measured by water displacement. Dispersion of the sediment was facilitated by the addition of a small amount of $\mathrm{KOH}(10 \%)$. The sediment was sieved through $500 \mu \mathrm{m}$ and $125 \mu \mathrm{m}$ mesh screens with a gentle spray of tap water. The residue was examined systematically under a stereo-microscope at $\times 12$ magnification. Remains of interest were picked out, identified, and counted. Identification was aided by comparison with reference material and photographs and images from atlases and identification keys (see Birks, 2001).

The chronological framework of Sáez et al. (2009) (Table 2) has been refined with the addition of new radiocarbon dates that date more precisely the duration of the sedimentary hiatus in the upper part of the composite sequence (Fig. 2). In this paper, all radiocarbon dates have been recalibrated using CALIB 6.02 software and the INTCAL09 database (Reimer et al., 2009) for samples younger than $20,000{ }^{14} \mathrm{C}$ years. Older samples have been calibrated with CalPal (Danzeglocke et al., 2008) (Table 2).

The macrofossil taxa were ordered on the basis of their weighted average (WA) by depth (Janssen and Birks, 1994) using C2 1.4 software (Juggins, 2003) to sort them according to their commonest depth, in increasing order. The macrofossil data were plotted using psimpoll 4.26 (Bennett, 2002) and the diagram was zoned by optimal splitting by information content (Bennett, 1996). The overall temporal trends of the macrofossil data along the sequence were summarised using correspondence analysis (CA) after logarithmic transformation of the concentration data. Rare taxa were downweighted. This analysis assumes a unimodal response model (Jongman et al., 1995), which is the usual case for species-environment relationships (Birks et al., 2010). A principal components analysis (PCA) identified the main stratigraphical variations in the sedimentary and geochemical data previously measured by Sáez et al. (2009) (see Supplementary Material). PCA 
N-S

LFP

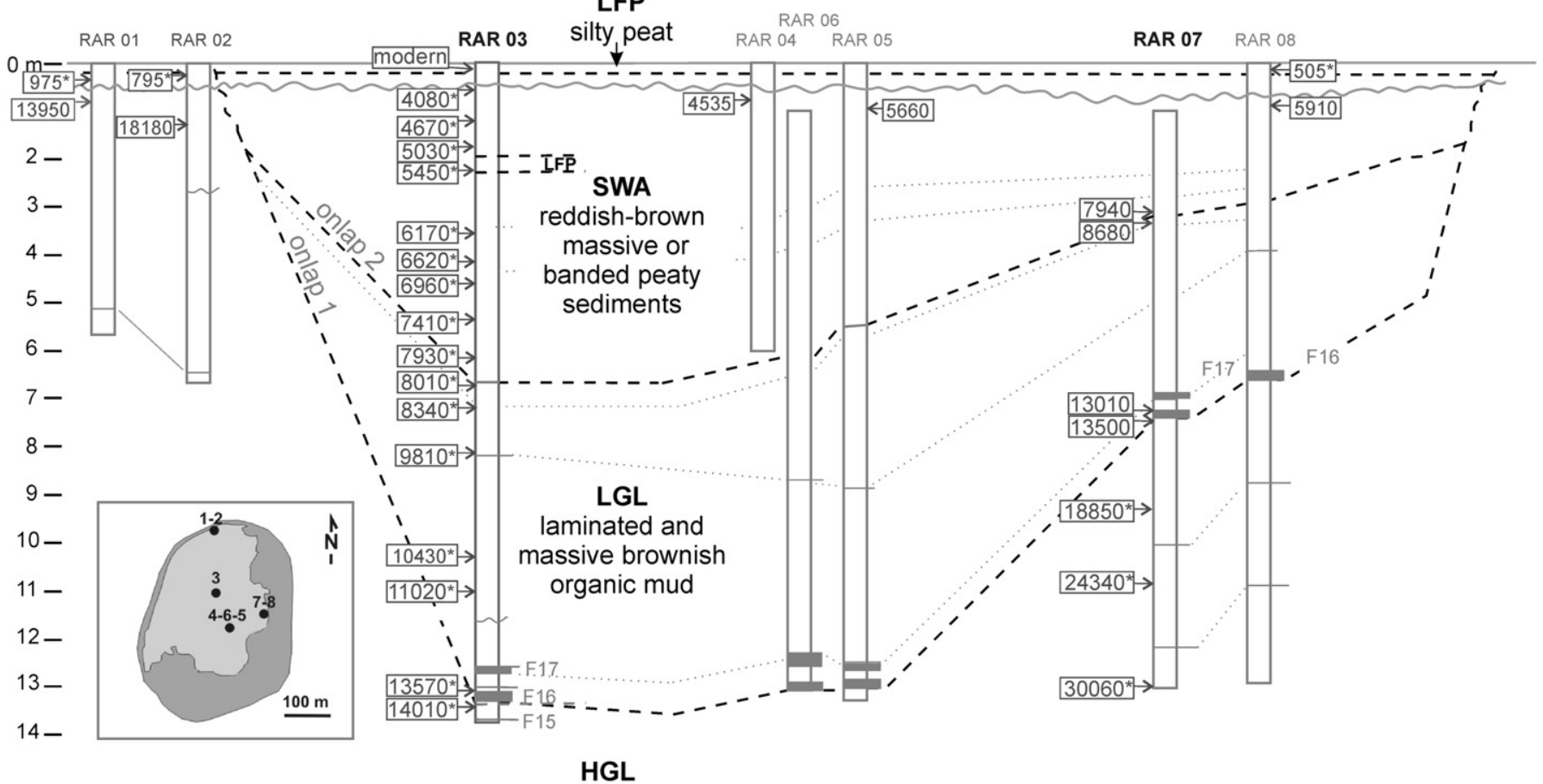

laminated, dark grey-reddish silty mud

$\sim$ erosive surface $\quad 14010 \rightarrow$ radiocarbon date (years BP)

F17 interval dark grey mud

- - - . Facies association boundaries

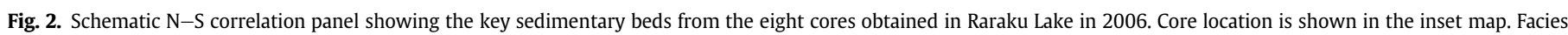

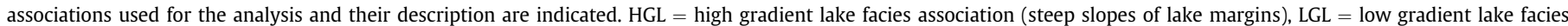

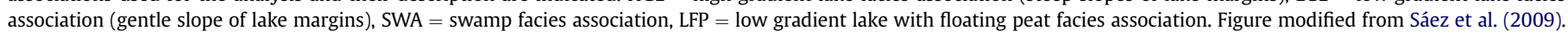

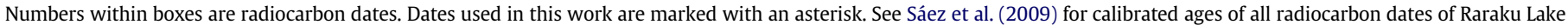
and Table 2 for the dates used in this work.

assumes lineal response, which is usually considered for this kind of data. These parameters include: magnetic susceptibility (ms) measured using a multi-sensor core logger, total nitrogen (TN) and total carbon (TC) measured using an elemental analyser, bulk $\delta^{15} \mathrm{~N}$ and $\delta^{13} \mathrm{C}$ determined by IRMS in a continuous flux mass spectrometer assembled on line to an elemental analyser, and the total content of $\mathrm{Si}, \mathrm{Ti}, \mathrm{S}, \mathrm{Fe}, \mathrm{Ca}$ and a value of X-ray incoherence/ coherence ratio [inc_coh_ratio] (as a proxy of organic matter) determined by X-ray fluorescence using a core scanner. The nine facies described by Sáez et al. (2009) have been grouped into four facies associations as described above (Section 2) and incorporated into the analysis. Both indirect analyses (PCA and CA) were done with R software package (R Development Core Team, 2008). To identify the major structure in the macrofossil data two-way indicator species analysis (Hill, 1979) was carried out with TWINSPAN (version 2.3, M.O. Hill 1979, modified by C.J.F. ter Braak,
H.J.B. Birks, and P. Šmilauer). This method is widely used in community ecology to construct a hierarchical classification by successive dichotomous division of the data. It is a semiquantitative method as some quantitative aspects of the data are retained by delimiting pseudospecies (see Hill, 1979). Significant groups were determined using TWINDEND (version 0.4, J. M. Line and H.J.B. Birks, unpublished), which evaluates the explanatory power of each TWINSPAN division in the hierarchical classification, calculating the mean internal dispersion (or heterogeneity) of the TWINSPAN groups at each division level as a percentage of the mean dispersion of the total data. TWINSPAN classification is an informative and robust method for detecting structure in noisy and heterogeneous data-sets (Gauch and Whittaker, 1981). The program DISCRIM (version 1.2 a modification of TWINSPAN by C.J.F. ter Braak, modified by J.M. Line and H.J.B. Birks) was used to relate the external geochemical and sedimentary data to the

Table 1

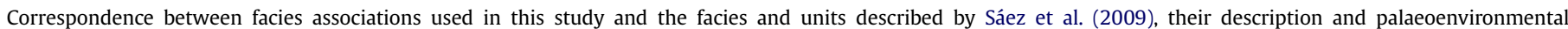
interpretation.

\begin{tabular}{|c|c|c|c|c|}
\hline $\begin{array}{l}\text { Facies association } \\
\text { this study }\end{array}$ & $\begin{array}{l}\text { Facies } \\
\text { Sáez et al. (2009) }\end{array}$ & $\begin{array}{l}\text { Units } \\
\text { Sáez et al. (2009) }\end{array}$ & Description & Palaeoenvironmental interpretation \\
\hline HGL & Facies 1,2 & Unit 1 , bottom Unit 2 & $\begin{array}{l}\text { Laminated grey-reddish, muddy silt } \\
\text { with frequent turbidite layers }\end{array}$ & High gradient lake (steep slopes of lake margins) \\
\hline LGL & Facies $4,5,6,7$ & Mid and upper Unit 2 & $\begin{array}{l}\text { Laminated- coloured and banded- massive } \\
\text { brown organic mud with rare turbidite layers }\end{array}$ & Low gradient lake (gentle slope of lake margins) \\
\hline SWA & Facies 8 & Units $3,4 a$ & Reddish peat & Swamp \\
\hline LFP & Facies 9 & Unit 4b & Silica-rich silty peat with diatoms & Low gradient lake with floating peat \\
\hline
\end{tabular}


Table 2

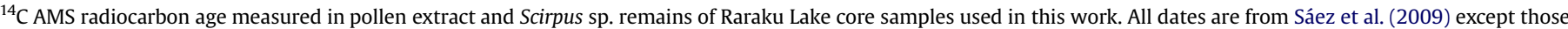

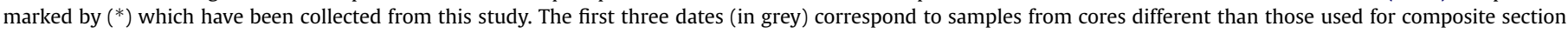

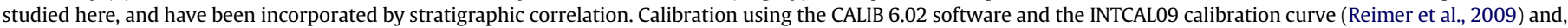
for samples older than 20000 radiocarbon years BP., CalPal (Danzeglocke et al., 2008).

\begin{tabular}{|c|c|c|c|c|c|c|c|}
\hline Sample name & Laboratory name & Composite depth (m) & Fraction dated & ${ }^{14} \mathrm{C}$ yr BP & \pm & Dates (cal yr BP) & \pm \\
\hline RAR08.01.12-13 & Poz-32007 & 0.125 & Pollen extract & $505^{*}$ & 30 & 528 & 25 \\
\hline RAR02.01.20 & Poz-19933 & 0.25 & Pollen extract & 795 & 35 & 721 & 49 \\
\hline RAR01.01.37 & Poz-19930 & 0.37 & Pollen extract & 975 & 30 & 866 & 71 \\
\hline RAR03.01.54 & Poz-33774 & 0.54 & Pollen extract & $4080^{*}$ & 40 & 4576 & 80 \\
\hline RAR03.02.27 & Poz-33775 & 1.28 & Pollen extract & $4670 *$ & 40 & 5394 & 82 \\
\hline RAR03.02.85bis & Poz-20571 & 1.85 & Scirpus macrorest & 5030 & 40 & 5801 & 96 \\
\hline RAR03.03.30 & Poz-19935 & 2.30 & Pollen extract & 5450 & 40 & 6247 & 62 \\
\hline RAR03.04.55 & Poz-24027 & 3.55 & Scirpus macrorest & 6170 & 40 & 7059 & 110 \\
\hline RAR03.05.14 & Poz-24030 & 4.14 & Scirpus macrorest & 6620 & 50 & 7504 & 70 \\
\hline RAR03.05.65 & Poz-18689 & 4.65 & Pollen extract & 6960 & 40 & 7778 & 88 \\
\hline RAR03.06.34 & Poz-24031 & 5.34 & Scirpus macrorests & 7410 & 50 & 8261 & 103 \\
\hline RAR03.07.15 & Poz-24032 & 6.15 & Scirpus macrorests & 7930 & 50 & 8806 & 178 \\
\hline RAR03.07.83 & Poz-18690 & 6.83 & Pollen extract & 8010 & 40 & 8879 & 132 \\
\hline RAR03.08.33 & Poz-18691 & 7.33 & Pollen extract & 8340 & 50 & 9361 & 120 \\
\hline RAR03.09.35 & Poz-19936 & 8.35 & Pollen extract & 9810 & 60 & 11240 & 116 \\
\hline RAR03.11.10 & Poz-18693 & 10.39 & Pollen extract & 10430 & 50 & 12318 & 212 \\
\hline RAR03.12.10 & Poz-18694 & 11.25 & Pollen extract & 11020 & 50 & 12896 & 191 \\
\hline RAR03.14.40 & Poz-18696 & 13.39 & Pollen extract & 13570 & 70 & 16699 & 234 \\
\hline RAR03.14.60 & Poz-18695 & 13.59 & Pollen extract & 14010 & 70 & 17043 & 218 \\
\hline RAR07.09.10 & Poz-19938 & 15.27 & Pollen extract & 18850 & 130 & 22566 & 411 \\
\hline RAR07.10.85 & Poz-19939 & 16.95 & Pollen extract & 24340 & 230 & 29112 & 483 \\
\hline RAR07.11.140 & Poz-18705 & 18.97 & Pollen extract & 30060 & 240 & 34229 & 192 \\
\hline
\end{tabular}

TWINSPAN classification of the biological data (Ter Braak, 1986). This method constructs simple discriminant functions and classifies attributes given a hierarchical classification analysis (in our case a TWINSPAN classification) of the external macrofossil data, with the aim of discovering which external variables are most closely associated with and most strongly discriminate between different a priori groups of samples based on their macrofossil composition. In the DISCRIM analysis we incorporated some geochemical parameters -total organic carbon (TOC), total inorganic carbon (TIC), C:N ratio, and total sulphur (TS)- that were not taken into account in the PCA to avoid possible overweightings. All quantitative data were transformed into ranges with MILTRANS (version 2.5; C.J.F. ter Braak, J.M. Line, and H.J.B. Birks) prior to being used in DISCRIM. Some geochemical parameters and biological data were plotted as box-whisker plots to highlight visually the differences between the biosedimentological units.

\section{Results and interpretation}

\subsection{Macrofossil analysis}

The most common remains in the Raraku core are Cyperaceae fruits, Solanaceae seeds, fern sporangia and scales, moss and lichen remains, oribatid mite fragments, cladoceran ephippia, chironomid capsules, coleopteran fragments, and other unidentified remains (Fig. 3). The remains have been named with a code (IBB-) for further study and included in a general reference collection of biological micro- and macroremains kept at the Botanical Institute of Barcelona. Four macrofossil assemblage zones have been statistically defined (Fig. 4).

Zone MA-1 (18.9-12 m, 34-14.6 cal kyr BP) has a low plant macrofossil content, with very few, small vegetative macroremains of sedges and grasses. The main characteristics of this zone are the abundance of IBB-65 (likely a stellate trichome) and the presence of moss (IBB-89, IBB-92, IBB-96) and lichen (IBB-87) remains. Fern sporangia (IBB-63) and some animal remains are consistently present in low amounts.

Zone MA-2 (12-6 m depth, 14.6-8.7 cal kyr BP) is the most heterogeneous section with the lowest macrofossil quantity and diversity. The most distinctive remains are cladoceran ephippia (IBB98 ), which appear at the top of zone MA-1 and extend up to the end of MA-2, and likely cladocera eggs (IBB-72) with an irregular presence but a concentration in this zone. Solanaceae seed is confined to this zone. Mosses and lichens disappear and trichomes decrease until they disappear at the end of the zone. Fern sporangia and oribatid mites also decline in abundance but increase again near the top of the zone together with coleopteran remains (IBB-58, IBB-61, IBB-64), and Cyperaceae seeds, mainly Cyperaceae-2 (IBB62 , Scirpus seed), associated with sedge and grass vegetative remains. Cladocera and ferns show marked maxima near the top of this zone.

Zone MA-3 (6-1.5 m depth, 8.7-5.5 cal kyr BP) contains many large vegetative remnants of sedge and grass. Below $5 \mathrm{~m}$, Cyperaceae-2 fruits (IBB-62, Scirpus) are dominant, and fern sporangia and scales are frequent. The latter finally disappear at about $4 \mathrm{~m}$. Towards the top of the zone, Cyperaceae- 1 (IBB-60, Cyperus cf.) becomes frequent. Other characteristics are the presence of IBB-111, the highest abundance of oribatid mites, chironomids, some insect remains (IBB-51, IBB-52, IBB-57, IBB-58, IBB-61, IBB-64), and the presence of a large variety of other remains in low amounts.

A dominance of large sedge and grass vegetative fragments continues into Zone MA-4 (1.5-0 m depth, 5.5 cal kyr-present). Cyperaceae-2 fruits are abundant, together with reduced amounts of fern sporangia, oribatid mites, chironomids, Cyperaceae- 1 fruits, and other insect remains (IBB-51, IBB-52, IBB-57, IBB-58, IBB-61, IBB-64). At the top, a subzone (MA- $4 \mathrm{~b}$, around 800 cal years $B P$ to present), can be distinguished by the presence of charcoal, Plumatella (IBB228), chironomids (IBB-54), Cladocera ephippia, and the appearance of IBB-188, IBB-194, IBB-199, IBB-218, among others. The two uppermost samples (about 500 cal years BP) are differentiated by peaks of charcoal and traces of macrofossils that have not appeared before (Cyperaceae-3, IBB-166, among others).

Correspondence analysis (CA) based on the abundance of macroremains summarises the stratigraphical or temporal patterns in the macrofossil data (Fig. 5). Five axes are significant according to the broken-stick model, explaining $68.24 \%$ of the total variability. In the plane defined by the first two CA axes 

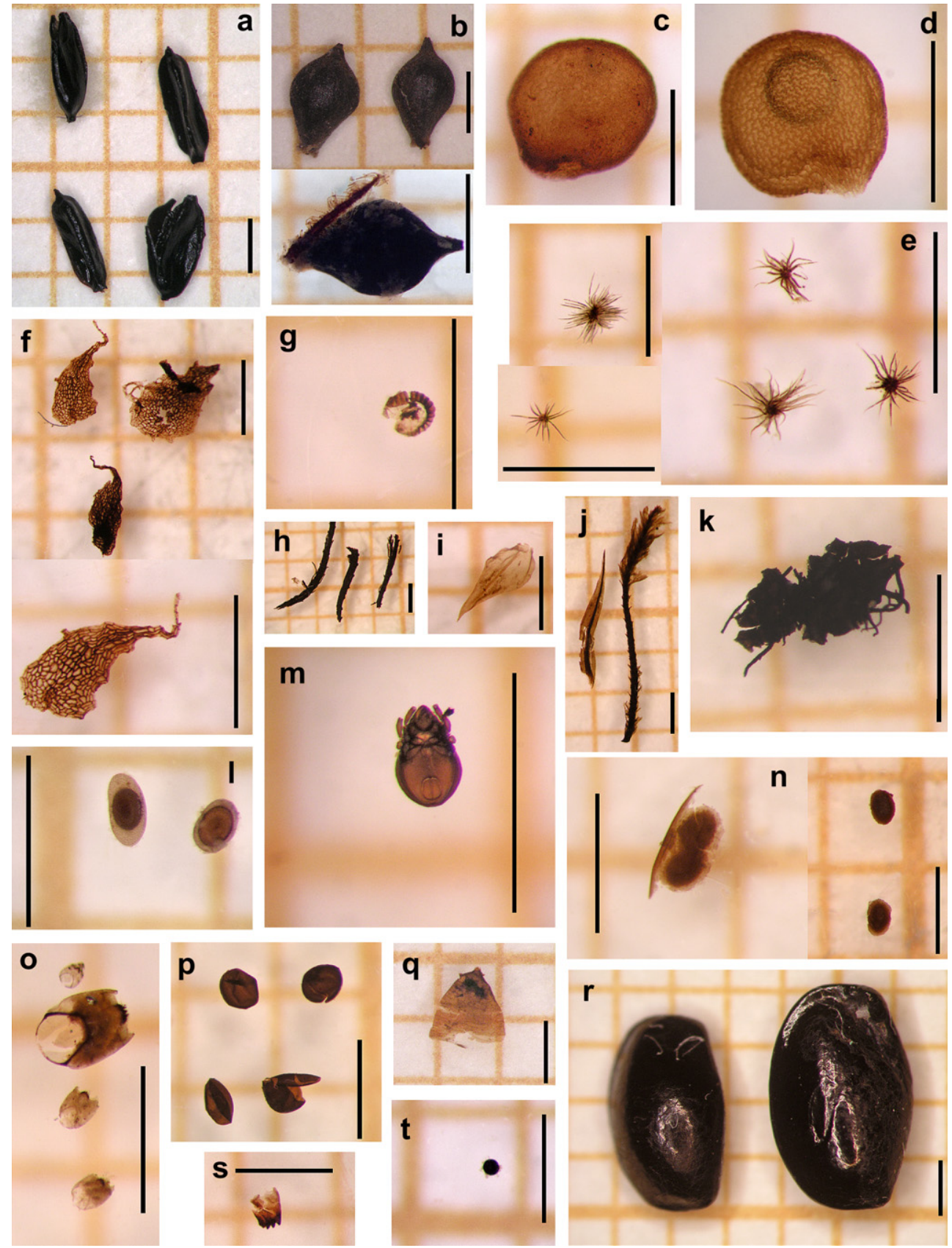

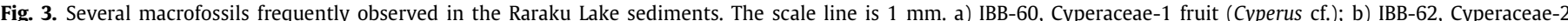

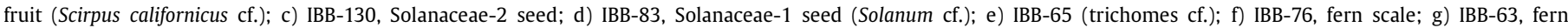

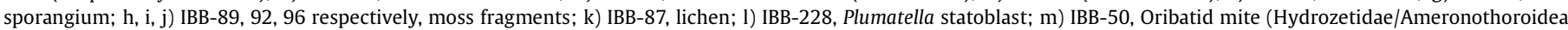

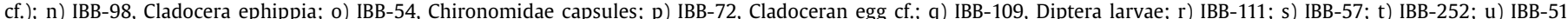

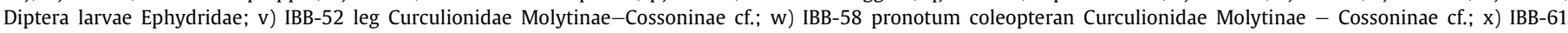

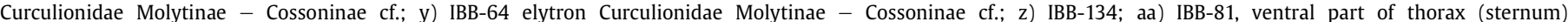

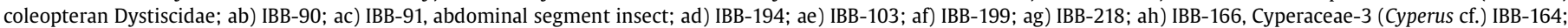
ai) IBB-166; aj) IBB-188; ak) IBB-59; al) IBB-168; am) IBB-162; an) IBB-128; ao) IBB-122; ap) IBB-148; aq) IBB-131; ar) IBB-106; as) IBB-94; at) IBB-108.

(39.8\% of variance explained) the samples from each macrozone are grouped together (Fig. 5a). Samples from MA-1 are joined in a very homogeneous group in the low right quadrant. Samples from MA-2 are distributed loosely in the upper right of the CA plot reflecting the heterogeneity within this zone. The MA-3 and MA-4 samples are situated in the lower left quadrant, with samples from MA-4 being closer to the negative end of axis 1 . When the axis scores are plotted stratigraphically, they summarise the main changes in the site (Fig. 5b). Axis one shows little difference between zones MA- 1 and MA-2, as shown by their position on the first axis of the CA plot (Fig. 5a). In contrast, axis 2 separates samples in MA-2, reflecting its heterogeneous composition and the different macroremains observed in the samples from a shallow lake environment (Fig. 5b). Both axes show a strong change from lake assemblages in MA-2 to peat assemblages rich in Cyperaceae remains in MA-3 (Fig. 5b). 

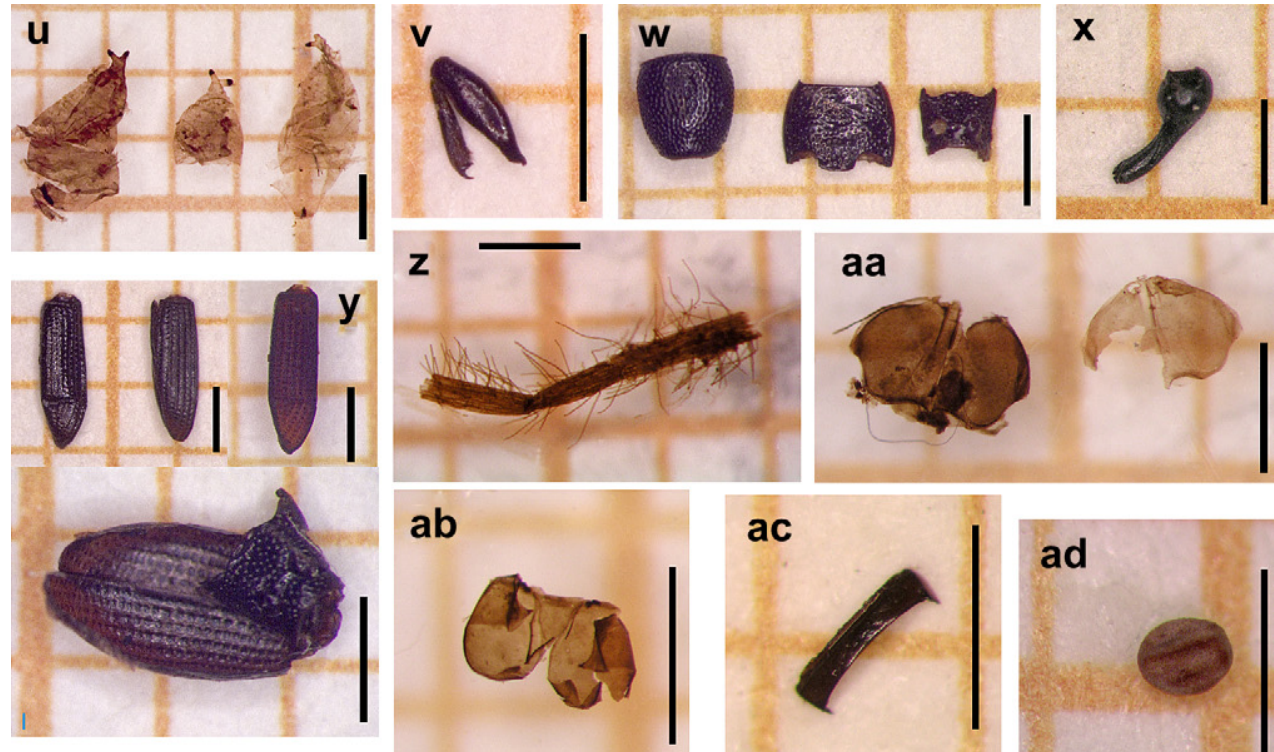

ac
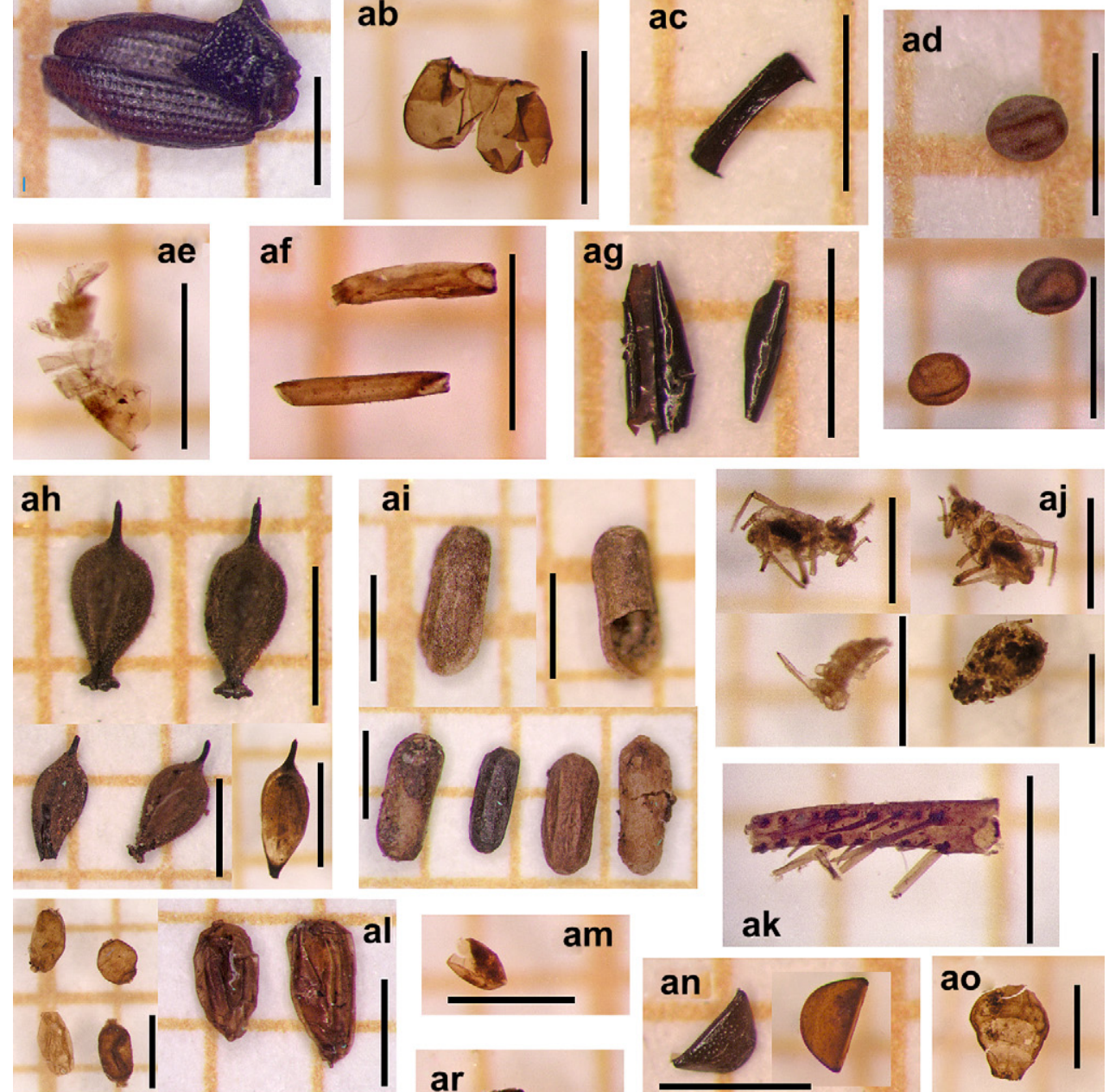

al
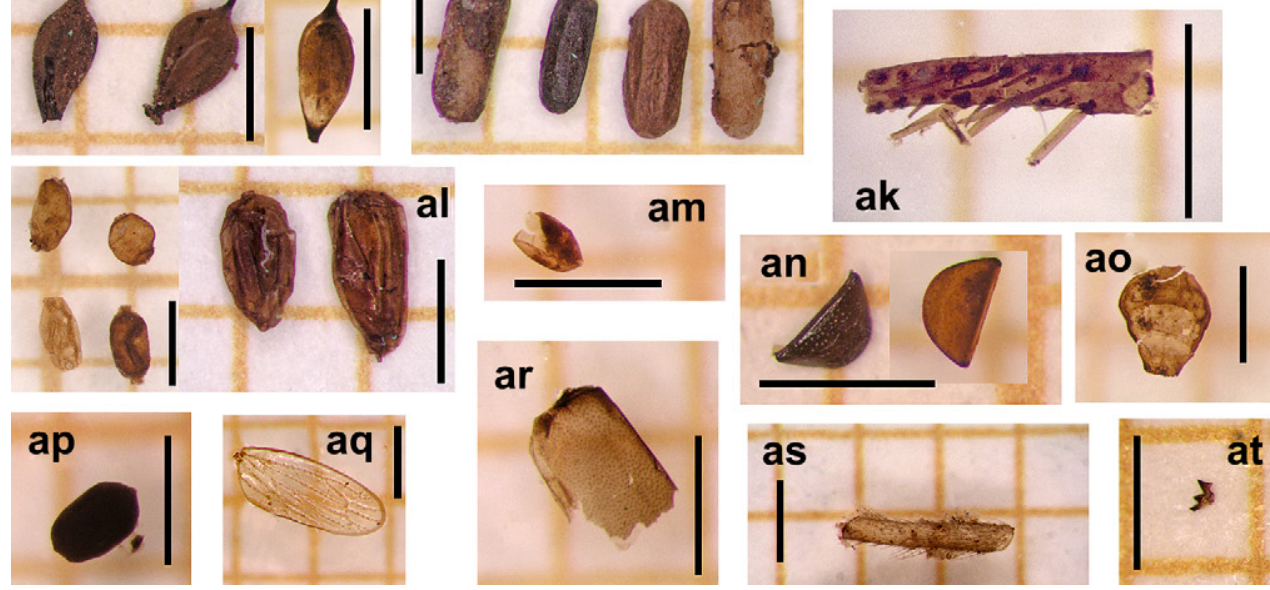

Fig. 3. (continued).

\subsection{Litho-geochemical PCA}

PCA of the geochemical and lithological data shows a strong stratigraphic/temporal pattern (Fig. 6). The two significant axes, according to the broken-stick model (69.8\% of the total variance explained) in the biplot separate four distinct groups (Fig. 6a). Samples below $13 \mathrm{~m}$ have high values of magnetic susceptibility, Fe,
$\mathrm{Ti}$, and $\mathrm{Si}$, and are grouped as the High Gradient Lake facies association on the positive side of PCA axis 1 suggesting a high terrigenous input into the lake by run-off. They are clearly separated from the organic-rich lacustrine mud with algal laminations and lacustrinepeat sediments on the negative side with low values of $\mathrm{Fe}, \mathrm{Ti}$, and Si. Axis 1 (eigenvalue $=8.79$ ) reflects the gradient of allochthonous/autochthonous input to the sediment. PCA axis 2 could be 


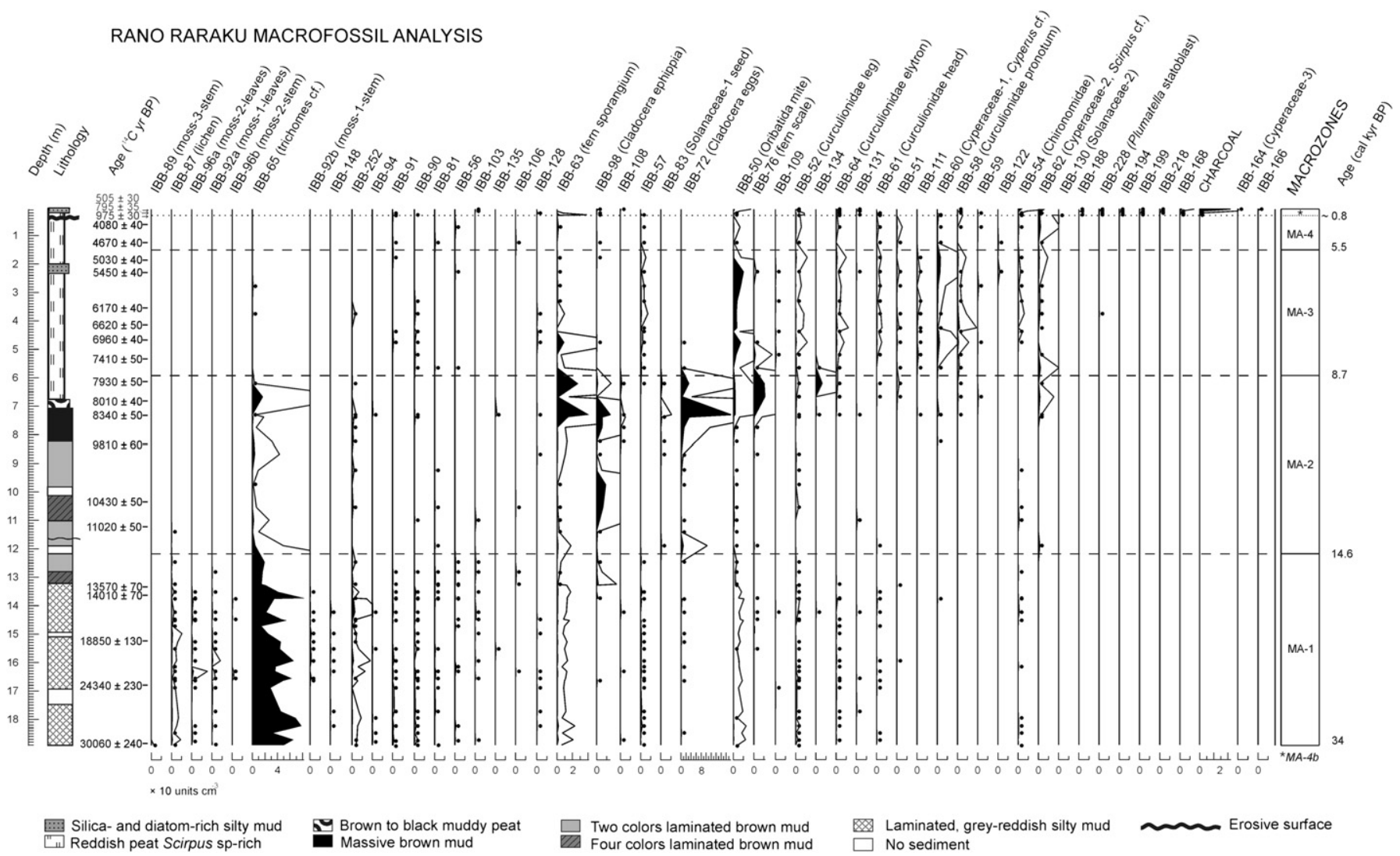

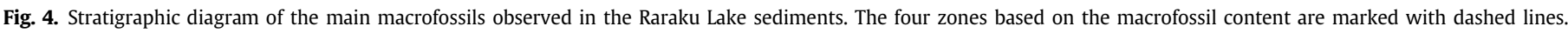

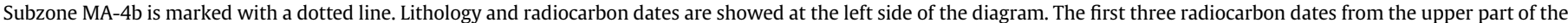

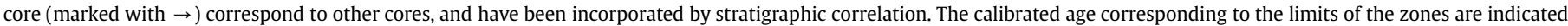
at the right. See Table 2 for radiocarbon age details.

interpreted as reflecting redox conditions. Samples associated with the Low Gradient Lake facies association are grouped at the positive end of PCA axis 2 and are related to high values of total nitrogen. Samples from peat sediments, mostly associated to the Swamp facies association, are grouped at the negative end and correlate with the high $\delta^{15} \mathrm{~N}$ values that are related to denitrification associated with anoxic conditions. The uppermost samples are localised in the centre, showing transitional conditions between the extreme a

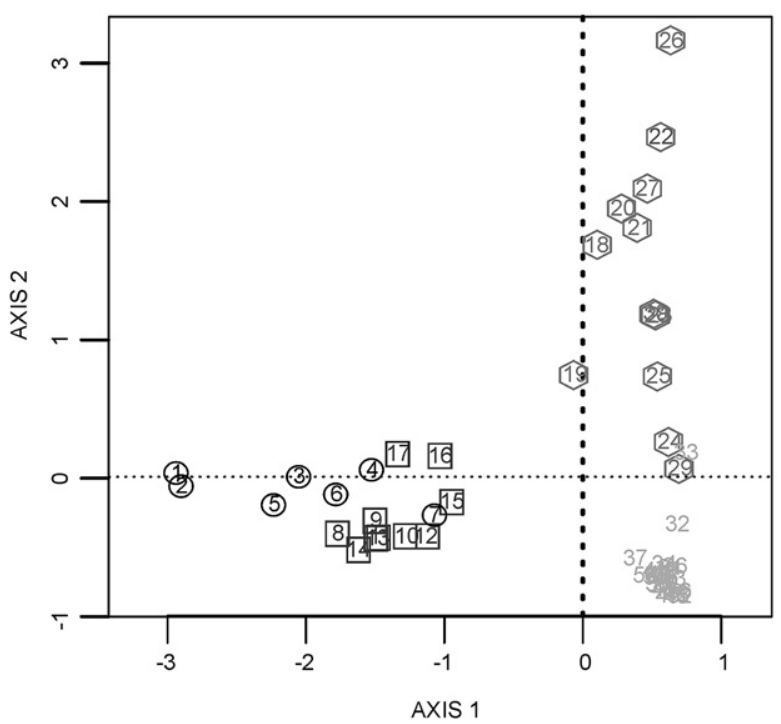

b

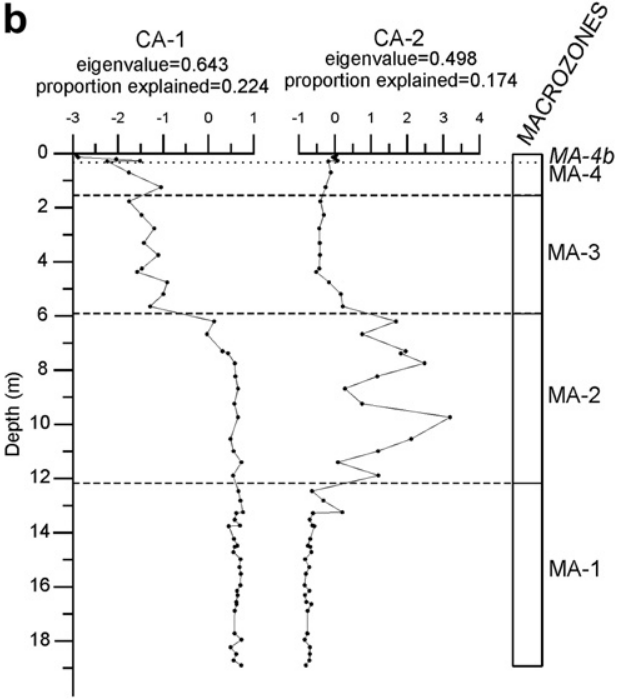

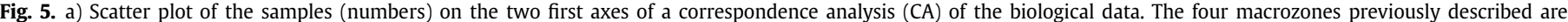

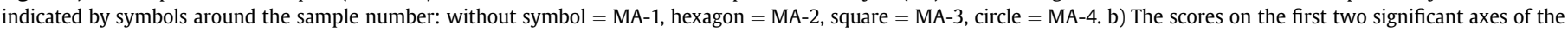
correspondence analysis (CA) plotted stratigraphically. Macrozones are indicated at the right. 
a

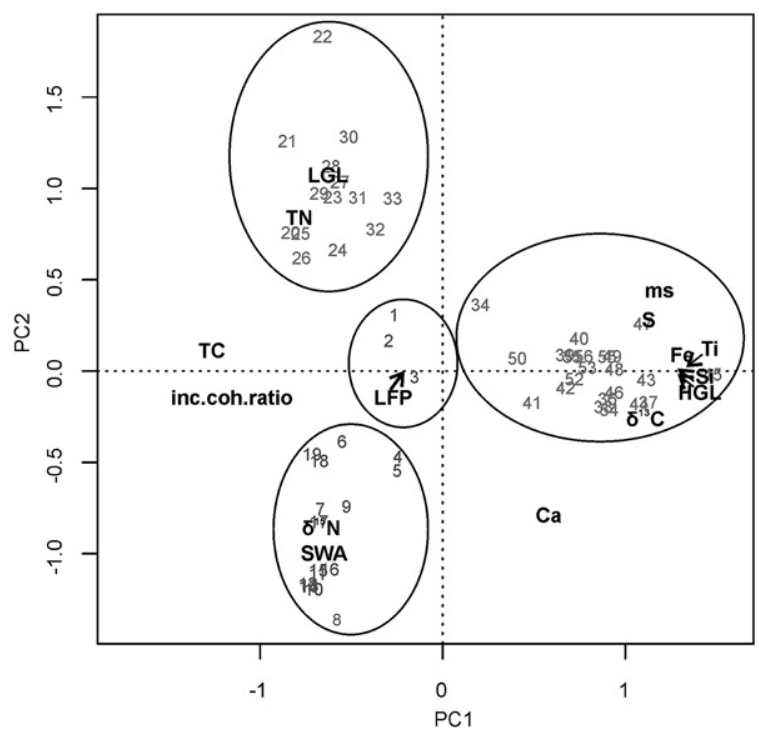

b

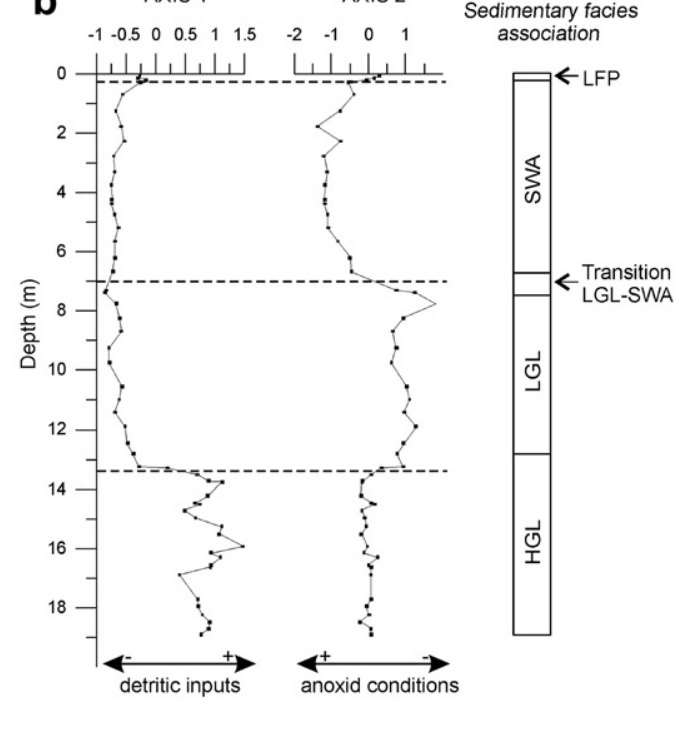

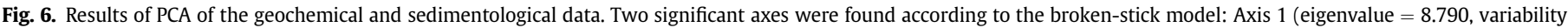

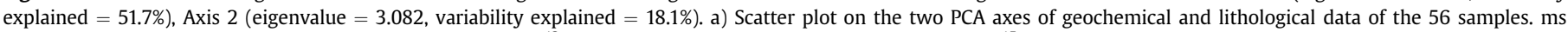

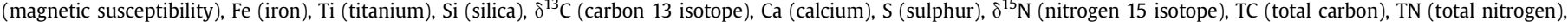

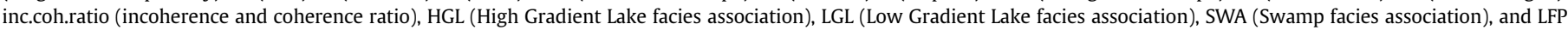

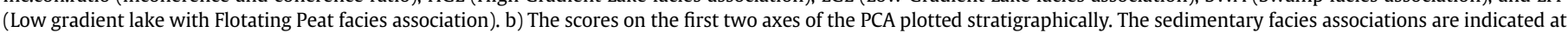
the right.

groups. When plotted stratigraphically (Fig. 6b) the major changes at $13.7 \mathrm{~m}$ reflect the end of allochthonous input and the major changes at $7 \mathrm{~m}$ indicate increased anoxia within the peat sediments.

\subsection{TWINSPAN and DISCRIM analyses: relationship between macrofossil, geochemical, and sedimentary data}

To relate the macrofossil changes to the geochemical changes, TWINSPAN and DISCRIM analyses were undertaken. Six significant groups of samples are differentiated by the TWINSPAN and TWINDEND analyses (Fig. 7). Two of them are small, with 2 and 4 samples. These 6 samples are amalgamated in Group A and are the uppermost samples in the sequence, being differentiated from all the other samples by the high abundance of Cyperaceae seed-2 (IBB-62). The DISCRIM analysis associates high values of total carbon (TC) and total nitrogen (TN) and low values of $\delta^{15} \mathrm{~N}, \delta^{13} \mathrm{C}$ and total inorganic carbon with this group. Group B (12 samples) derives from the second division in TWINSPAN within the large sample group. It contains samples 7 to 19 (except sample 18) whose indicator taxa are Cyperaceae-2 (IBB-62), IBB-111, Cyperaceae-1 (IBB-60), coleopteran pronota (IBB-58) and high abundance of oribatid mites (IBB-50). DISCRIM relates this group to $\delta^{15} \mathrm{~N}$ and the Swamp Facies association SWA, associated with Scirpus sp-rich reddish peat. The third TWINSPAN division separates the 38 remaining samples into Group C (10 samples) and Group D (28 samples). Group $C$ has IBB- 83 and IBB-72 as indicator taxa. The indicator taxa of Group D are IBB-65 and IBB-87 which are related to high values of Fe by DISCRIM.

The sedimentary facies, the psimpoll zones, and the TWINSPAN groups are compared in Fig. 8. They are closely similar. Group A corresponds to MA-4 although the deepest sample of this zone is not included in the group. Group B corresponds to MA-3 plus one sample from MA-2 and one from MA-4, suggesting the existence of transitions between the macrozones. Unlike other zonations, the TWINSPAN analysis is not stratigraphically constrained and allows samples above or below the zone boundaries to be partitioned into different groups and to highlight patterns of similarities between samples that are not necessarily stratigraphically adjacent (see Grimm et al., 2011). Group C consists primarily of samples from MA-2 plus the lowest sample from MA-3 suggesting that the transition here is fast. Group D comprises samples from MA-1 plus three samples from MA-2, suggesting a gradual transition between these two zones.

\subsection{Palaeoecological history of Raraku Lake during the last 34,000 years}

The macrofossil sequence is closely correlated with the geochemical parameters and the sediment lithology, thus providing useful information for reconstructing the evolution and palaeoecology of the lake. The changes in the macrofossil assemblages in the Raraku sediments are likely to be a result of the interplay between: (1) lake ontology and catchment processes, (2) climatic changes, and (3) human activities in the last millennium. Five major environmental lake stages can be identified in the Raraku record over the 34,000 calibrated years BP (cal yr BP).

\subsubsection{Stage 1 (>34 to 14.6 cal kyr BP)}

Macrofossil assemblages during zone MA-1 are dominated by terrestrial material. The absence of aquatic organisms suggests a low lake primary productivity. The $\mathrm{C} / \mathrm{N}$ ratio is around or higher than 20, which is typical of terrestrial plants, in contrast to $\mathrm{C} / \mathrm{N}$ ratios of 4-10 for aquatic organic matter (Meyers, 1994; Kaushal and Binford, 1999; O'Reilly et al., 2005). The steep walls of the crater formed steeply sloping lake margins at the initial stage of the lake evolution, resulting in a high gradient lake (HGL) which allowed terrestrial material to reach the centre of the lake. Maybe high turbidity prevented colonisation by aquatic organisms, thereby explaining their absence in the record. Previous sedimentological and pollen studies also indicate that there were high terrigenous inputs from run-off, low evaporation rates, high water balance, and the coldest conditions in the last 34,000 cal years BP 


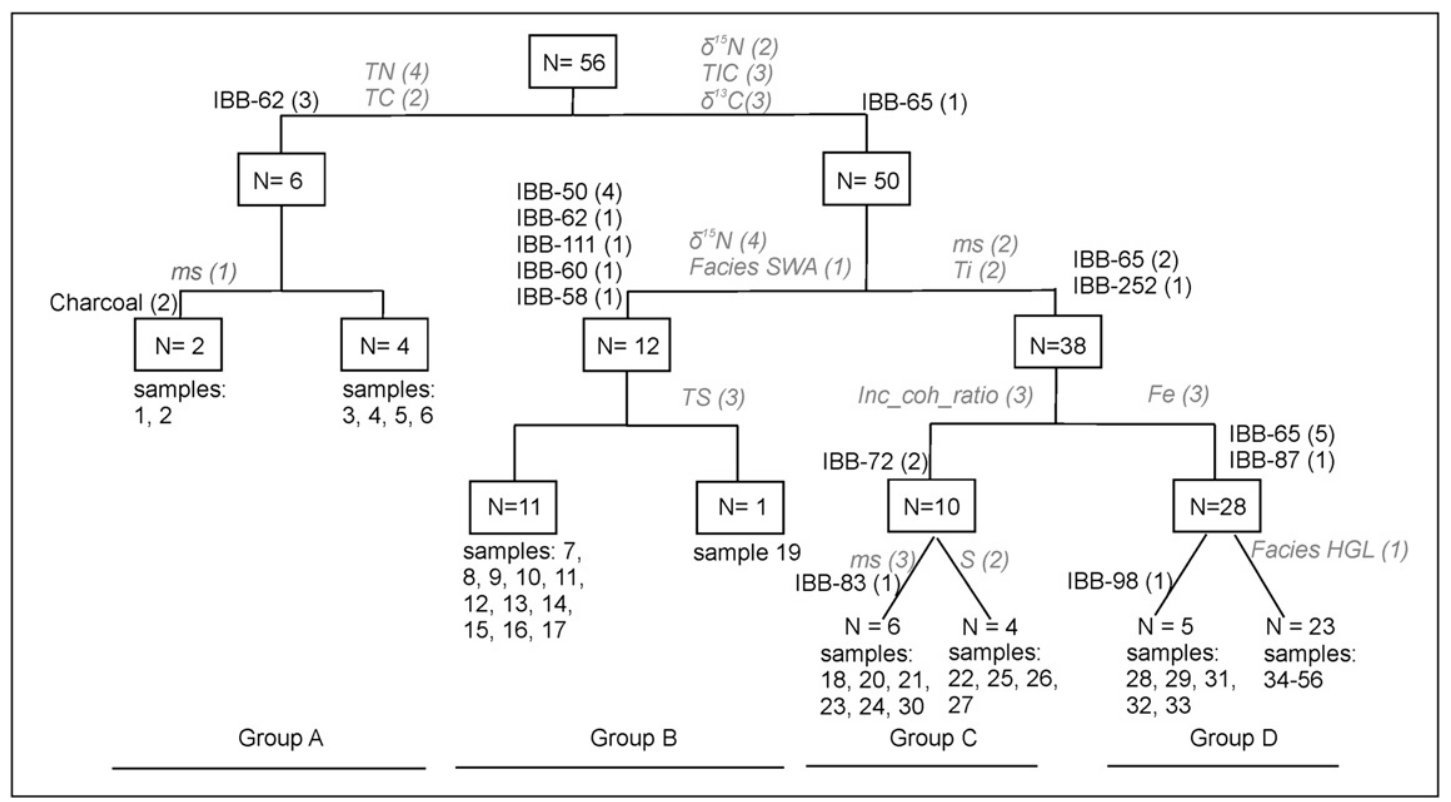

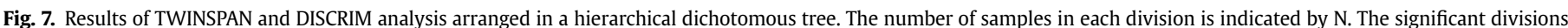

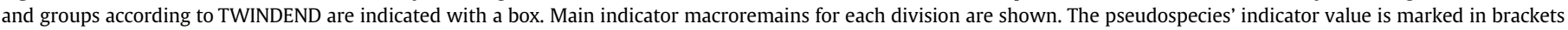

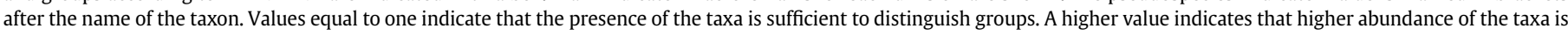

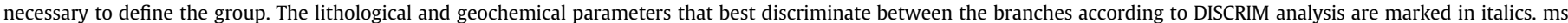

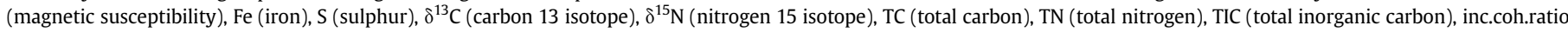

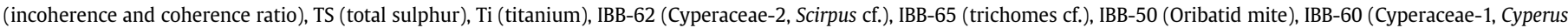

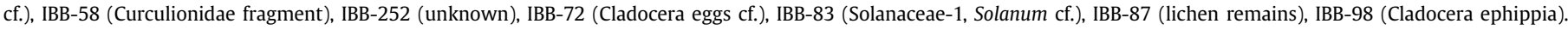
The samples in each division are placed in Groups A-D.

(Azizi and Flenley, 2008; Sáez et al., 2009). This stage corresponds to the last glacial period.

\subsubsection{Stage 2 (from 14.6 to 8.7 cal kyr BP)}

Gradual sedimentary infilling resulted in more gently sloping lake margins leading to the formation of a low gradient (LGL) lake with the development of a narrow littoral vegetation fringe in shallow water. The littoral plant communities became thicker and denser over time as shown by the records of Cyperaceae seeds and they prevented coarse terrigenous inputs characteristic of zone MA-1 from reaching the lake centre. The decrease in terrestrial input could also be related to increases in the vegetation cover in the catchment and stabilisation of the landscape in the warmer Holocene climate. The associated increases of Cladocera remains,

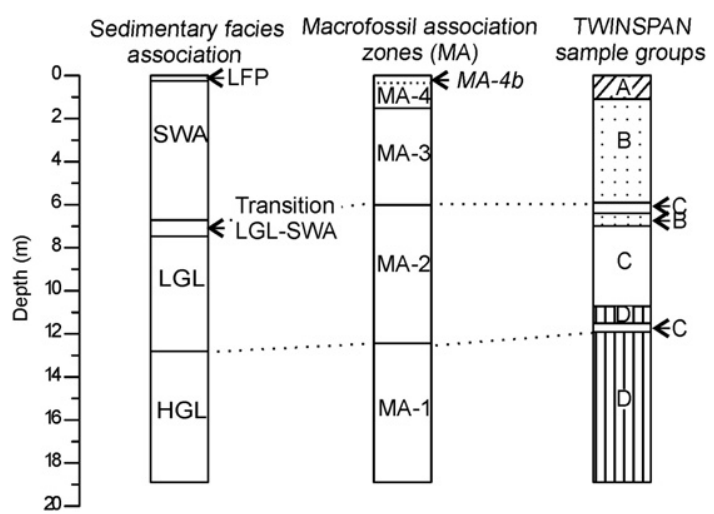

Fig. 8. Correspondence of the facies association, macrofossil zones and TWINSPAN groups. HGL = high gradient lake facies association (steep slopes of lake margins), LGL = low gradient lake facies association (gentle slope of lake margins), SWA = swamp facies association, LFP $=$ low gradient lake with floating peat facies association. total carbon, organic matter (measured by the incoherence/coherence ratio), and total nitrogen indicate the development of a more productive lake system or quieter waters. However, the $\mathrm{C} / \mathrm{N}$ ratios still suggest a mainly terrestrial origin for the high organic matter of the sediment, possibly derived from inwash of humus colloids as soils developed in the catchment and marginal lake sediments were eroded. Solanaceae- 1 could be an important component of the vegetation colonising the lake margins during this stage. The trend to a more productive lake with age is one of first signs of lake ontogeny under a warming climate (Kling, 2000). Warmer environmental conditions during the deglaciation also resulted in an increased evaporation over precipitation (E/P ratio) leading to a drop in lake-level which resulted in high detrital deposition from the erosion of exposed littoral sediments (occasional turbidite-like currents) during this stage (Sáez et al., 2009).

\subsubsection{Stage 3 (from 8.7 to $5.5 \mathrm{cal} \mathrm{kyr} \mathrm{BP}$ )}

Large vegetative fragments of sedges and grasses form the sediment during MA-3, suggesting a hydroseral succession into a swamp. Trends from high gradient lacustrine stages to low gradient, lacustrine-marsh peats are common in small, closed lakes in many climatic contexts when sedimentary processes result in the complete infilling of a lake basin (Sáez and Cabrera, 2002; Cohen, 2003). The invertebrate faunal remains are probably linked to the development of the swamp vegetation (Fig. 4) such as oribatid mites, a phytophagus group of beetles, the Curculionidae (Molytinae Cossoninae cf.), and many animal fragments. The transition from lacustrine (MA-2) to swampy (MA-3) conditions coincides with a high abundance of fern remains (sporangia, scales, leaf fragments), IBB-65, Solanaceae-1 seeds, IBB-72, Cyperaceae-1 (cf. Cyperus), and Cyperaceae-2 (Scirpus sp.) seeds. At least two explanations are possible for this peak of macroremains: an increase in the input of allochthonous material from the basin, or enhanced littoral vegetation development (mainly ferns and Scirpus) likely as a result of an 
increase in total nitrogen. Organic matter accumulation from swampy conditions and vegetation colonising the lake consumed high amounts of oxygen and nitrogen during their decay, and could have led to more anoxic conditions. High values of $\delta^{15} \mathrm{~N}$ measured during the stage 3 support this hypothesis.

\subsubsection{Stage 4 (from $5.5 \sim 0.8$ cal kyr BP)}

Although the sediment continues to be dominated by large fragments of sedges, suggesting the prolonged existence of a swamp, Scirpus sp. became dominant over Cyperus sp. in zone MA-4 at about 5.5 cal kyr BP, accompanied by a decrease in oribatid mites and weevil remains and the disappearance of IBB-111. This stage was interrupted by a sedimentary hiatus between 4.5 and 0.8 cal kyr BP. Widespread arid conditions during the midHolocene are documented in the Pacific area and are proposed as the cause of this sedimentary gap (Sáez et al., 2009), which has already been detected in other studies (Mann et al., 2008).

\subsubsection{Stage 5 ( $\sim 0.8$ cal kyr BP to present)}

Around $0.8 \mathrm{cal}$ kyr BP the record of swampy conditions resumed with a similar biotic composition as the previous stage, with the addition of some new biological remains and charcoal particles in zone MA-4b that are coincident with high values of nitrogen in the sediment (TN) (Fig. 7). The onset of a more humid period which created lacustrine conditions in Raraku is identified by a change in the sediment around 0.5 cal kyr BP that suggests a lake-level increase at the top of the sequence (low gradient lake with floating peat). This also corresponds to the addition of some new biological remains and peaks of charcoal particles in two uppermost samples of zone MA-4b (Figs. 4 and 7).

These changes could be associated, in part, with human presence around the lake. Moreover, the presence of charcoal fragments indicative of a higher fire incidence is commonly associated with human activities. Microcharcoal particles have previously been reported from Raraku cores at this level (Flenley et al., 1991; Mann et al., 2008) and interpreted to be a result of island deforestation. Some authors have proposed this deforestation as a cause of the collapse of the Rapa Nui civilisation (e.g. Flenley, 1993; Flenley and Bahn, 2003), but others attribute the forest decline and the cultural collapse to climatic changes (Dumont et al., 1998; HunterAnderson, 1998; Orliac and Orliac, 1998; Nunn, 2000; Orliac, 2000). Nevertheless, the existence of palm forests covering the island is still not convincingly demonstrated and other scenarios are possible in the light of the evidence currently available. Rull et al. (2010) have proposed a mosaic vegetation pattern with forests restricted to sites with a high freshwater table (gallery forest). Unfortunately, the chronological framework of this part of the Raraku core has not been reliably established since the radiocarbon dates are not consistent, and we cannot say anything new about the dates of this assumed human disturbance.

\section{Discussion}

The stratigraphical variation in the macrofossil sequence (Figs. 4 and 5) corresponds well to the sedimentary facies and geochemical changes (Fig. 6) in the Raraku sequence (Fig. 8). This agreement suggests that the sedimentation patterns were influential in the taphonomic processes that determined the presence of the biological remains in the sediment.

\subsection{Main sources of macrofossils and controlling factors in sediment composition}

It has been shown that macrofossil assemblages in lakes are usually deposited close to their source and thus reflect local communities (e.g. Birks, 1973; Zhao et al., 2006; DieffenbacherKrall, 2007). The main sources of macrofossils in lake sediments are the lake itself, the marginal vegetation, and the terrestrial catchment (Smol and Glew, 1992; Birks et al., 2000; Birks and Birks, 2006). In Rano Raraku's sediments, the composition of the lake and swamp vegetation and the intensity of run-off from the surrounding slopes are the main factors controlling the composition of the macrofossil assemblages. Groups A and B (Fig. 7) originated in swamp environments and shallow water that laid down peaty sediments, characterised by the dominance of sedge remains. In swamp environments plant remains are deposited on the spot where they grew forming an autochthonous macrofossil assemblage (Greenwood, 1991). The overall increase in animal remains in the peat probably derives from animals that were living in the swamp vegetation. On the other hand, assemblages in Group D (Fig. 7) seem to be strongly influenced by high amounts of run-off inputs which allowed terrestrial material from the catchment such as lichens, mosses, plant trichomes, etc. to be washed into the deep water of the lake centre. The absence of Cyperaceae seeds and other remains of typical littoral biota suggest a weak development of vegetation along the shore that would not hinder the input of terrestrial material. The same factors influenced macrofossil composition in Group C but catchment run-off decreased and coarse terrestrial material including macrofossils became rare or disappeared. The occurrence of Cyperaceae seeds suggests the development of a wider and denser littoral fringe of macrophytes, which would also have limited terrigenous transport to the lake centre. The macrofossil assemblage in Group C is related to the aquatic ecosystem, with the presence of remains of aquatic organisms such as Cladocera (ephippia and eggs) derived from the littoral communities.

\subsection{Palaeoecological indicator power of macrofossil remains}

Because few of the macroremains in the Raraku sequence could be identified to species, the relationships of the taxa to other environmental proxies needs to be established in order to make palaeoecological inferences from them. The TWINSPAN analysis resulted in the definition of four groups of samples (A-D; Fig. 7). In Fig. 9b we plot the occurrences of individual taxa within each group, to identify group in which they are most frequent. We have also plotted the values of geochemical parameters in each sample group (Fig. 9a). Using this information combined with their ecological affinities if known and their relationships to sedimentary data and the macrofossil zones (Fig. 8), they can be related to environmental conditions as in the discussion above.

Macrofossils can provide ecological and environmental information for the time when they were deposited. In Group D the high values of terrestrial remains, such as plant trichomes, lichens, and mosses, in association with high values of the erosion proxies magnetic susceptibility, Ti, and Fe (Fig. 9), are indicative of a sparsely vegetated catchment and a high gradient lake environment with high erosion and run-off inputs in the lake. In contrast, cladoceran remains and Solanaceae seeds, characteristic of samples from Group C (zone MA-2) are associated with high values of $\mathrm{N}$ and $\mathrm{C}$ (mainly organic carbon) and very low values of Ti, Fe, TIC, and $\delta^{13} \mathrm{C}$ (Fig. 9) that indicate fewer run-off events and quieter waters and the development of a shallow-water littoral zone. The presence of some Cyperaceae (cf. Cyperus) seeds indicates the development of sedge-swamp growing in shallow water, whereas high quantities of Cyperaceae seeds together with oribatid mites and coleoptera remains characterise peaty environmental conditions. These developed in Stage 3 (MA-3) where high values of $\delta^{15} \mathrm{~N}$ in the sediment represent more anoxic conditions (Ogawa et al., 2001). Other taxa, such as oribatid mites, coleopteran remains, 
a
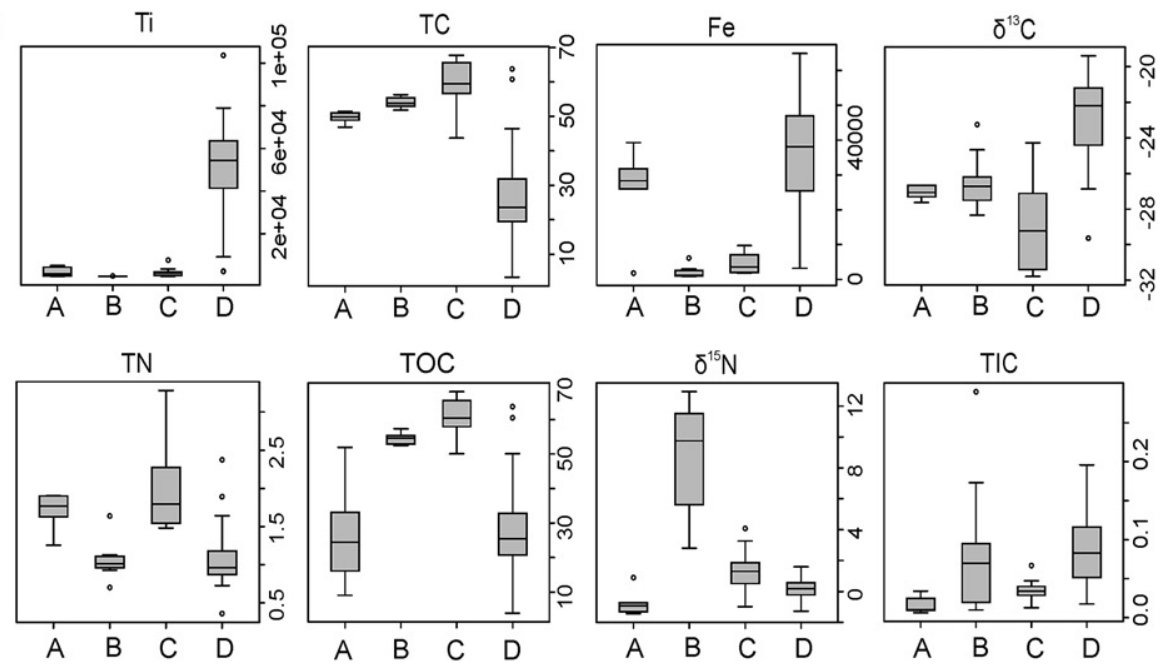

b

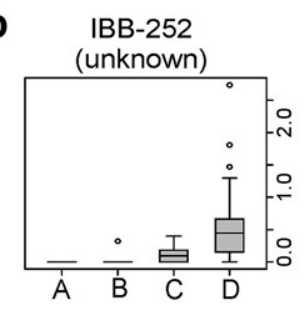

IBB-72
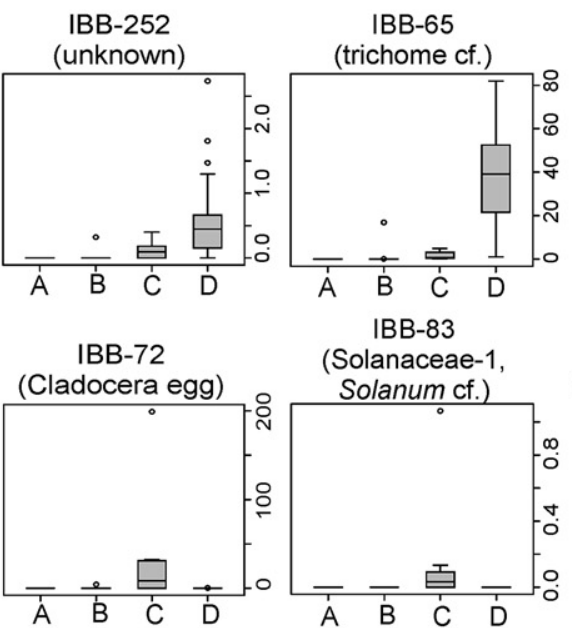

(Solanaceae-1,

Solanum cf.)

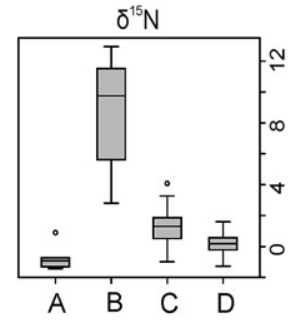

TIC

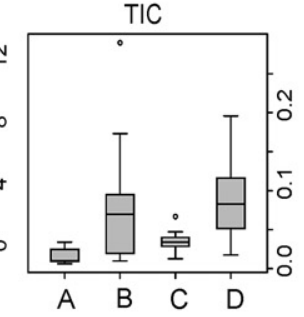

(moss remain)

IBB-87

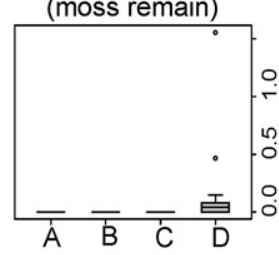

IBB-98

BB-63

(Cladocera ephippia) (fern sporangium)

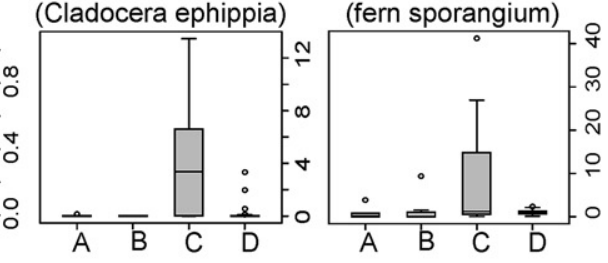

IBB-111

(unknown)

IBB-61

IBB-64

(Curculionidae remain) (Curculionidae remain)

IBB-50

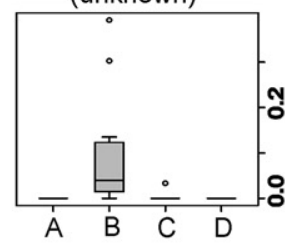

IBB-60

(Cyperaceae-1,

Cyperus cf.)

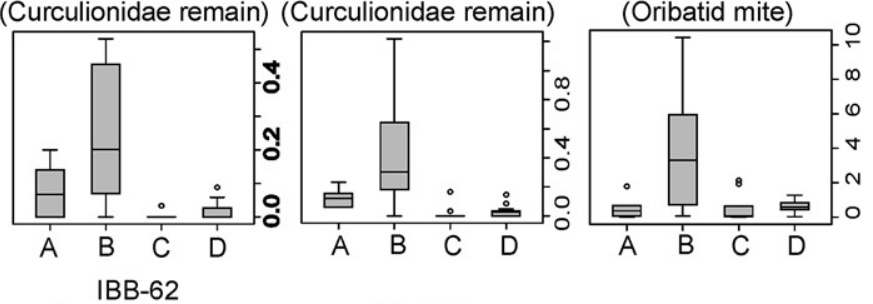

(Cyperaceae-2,

IBB-228
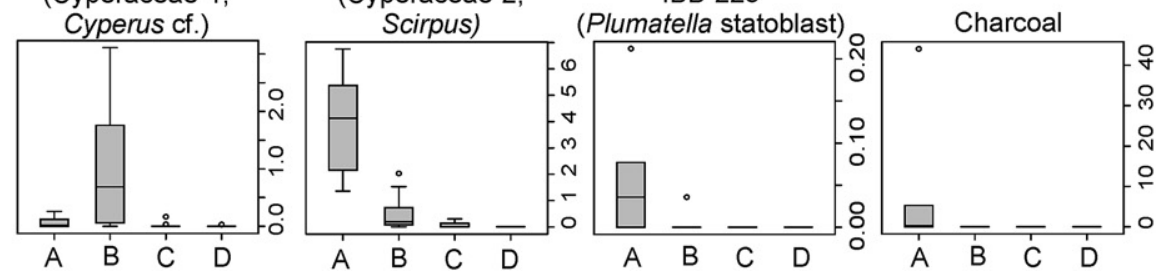

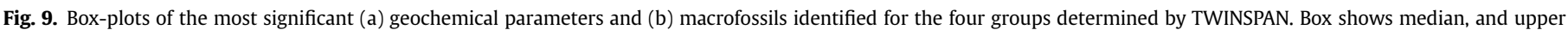

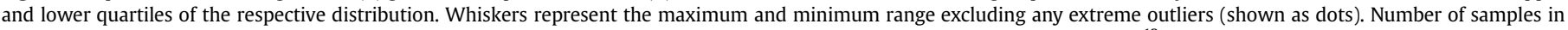

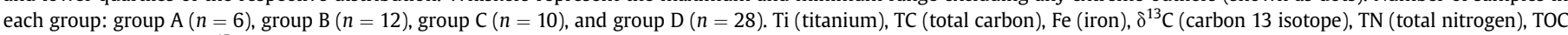
(total organic carbon), $\delta^{15} \mathrm{~N}$ (nitrogen 15 isotope), TIC (total inorganic carbon). 
the unidentified IBB-111, and Cyperaceae- 1 seeds characteristic of Group B (Fig. 7) indicate incipient peat formation and shallow water. The assemblage changes in Group A (MA-4) and high values of Cyperaceae seed-2 and Plumatella statoblasts reflect the local formation of shallow open water. Charcoal is derived from the catchment or beyond by water or air transport. Additional studies and more precise identifications, together with information from microfossil analysis, are needed to test the indicator value of past environmental conditions by the macrofossils at Rano Raraku.

\section{Conclusions and final remarks}

The macrofossil assemblages in the Rano Raraku sequence are greatly influenced by run-off intensity, the vegetation around and in the lake, and the water depth. Terrestrial remains, characterised by plant trichomes, lichens, and mosses, were transported to the lake by run-off from the catchment during the last glacial period. The development of catchment and littoral vegetation in the Holocene influenced the composition of the sediment. The early Holocene swamp fringe acted as a filter that reduced terrestrial inflow and provided locally produced organic material. The continued hydroseral development resulted in peat-forming fen vegetation that supported aquatic plants and animals such as oribatids, coleoptera, etc. Together with sedimentary characteristics and geochemical information, the macrofossils can be used to indicate particular palaeoenvironmental conditions.

The fragmented and unidentified macrofossil record in Raraku Lake hampers a precise reconstruction of the environment and the ontogeny of the lake and its catchment. More information on the taxonomy and autoecology of Easter Island's biota is essential to improve our palaeoecological reconstructions. The study of microfossil is in progress and is expected to complement these interpretations. Nevertheless, the combination of macrofossil, sedimentary, and geochemical data have characterised five palaeoenvironmental stages during the last 34,000 cal years, and have provided an outline of the biotic and environmental changes in and around the lake through time. From 34 to 14.6 cal kyr BP (last glacial period) the lake had low productivity and high terrigenous inputs. During the warmer conditions of the early Holocene, lower energy and a lower lake-level promoted the growth of a littoral plant belt that prevented the transport of terrestrial material into offshore zones. From 8.7 to 4.5 cal kyr BP (early- to mid-Holocene) a swamp dominated mainly by Cyperaceae, first Cyperus sp. and later Scirpus sp. occupied the entire basin and the sediment became more anoxic. At around 4.5 cal kyr BP (mid-Holocene) peat accumulation and dry conditions prevented further peat growth until about 800 cal yr BP when humidity allowed peat growth to resume. In recent centuries humidity increased further and a small shallow lake developed within the swamp (Fig. 1). Charcoal in the lake sediments records human activity.

\section{Acknowledgements}

This research was funded by the Spanish Ministry of Science and Education through the projects LAVOLTER (CGL2004-00683/ BTE), GEOBILA (CGL2007-60932/BTE) and CONSOLIDER GRACCIE (CSD2007-00067) and an undergraduate grant (BES-2008-002938 to N. Cañellas-Boltà). We are grateful to CONAF (Chile) and the Riroroko family for the facilities provided on Easter Island. We are also grateful to Bas van Geel, Geoffrey Lemdahl, Oliver Heiri, Emily Coffey, Garland Upchurch, Frode Ødegaard, Robert Anderson, Charles O'Brien, Torstein Solhøy, Fred Stauffer, Heinrich Schatz, Alice Telka, and members of the PALEOLIM mailing list who responded to the first author's request, for their help in the identification of and comments about the macrofossils found. This is publication nr. A 376 from the Bjerknes Centre for Climate Research.

\section{Appendix. Supplementary material}

Supplementary material associated with this article can be found, in the online version, at doi:10.1016/j.quascirev.2011.12.013.

\section{References}

Anderson, N.J., Brodersen, K.P., Ryves, D.B., McGowan, S., Johansson, L.S., Jeppesen, E., Leng, J., 2008. Climate versus in-lake processes as controls on the development of community structure in a low-Arctic lake (South-West Greenland). Ecosystems 11, 307-324.

Azizi, G., Flenley, J.R., 2008. The last glacial maximum climatic conditions on Easter Island. Quaternary International 184, 166-176.

Baker, P.E., Buckley, F., Holland, J.G., 1974. Petrology and geochemistry of Easter Island. Contributions to Mineralogy and Petrology 44, 85-100.

Battarbee, R.W., 2000. Palaeolimnological approaches to climate change, with special regard to the biological record. Quaternary Science Reviews 19, 107-124.

Bennett, K.D., 1996. Determination of the number of zones in a biostratigraphical sequence. New Phytologist 132, 155-170.

Bennett, K.D., 2002. Documentation for Psimpoll 4.10 and Pscomb 1.03, C Programs for Plotting Pollen Diagrams and Analysing Pollen Data. Uppsala University.

Birks, H.H., 1973. Modern macrofossil assemblages in lake sediments in Minnesota. In: Birks, H.J.B., West, R.G. (Eds.), Quaternary Plant Ecology. Blackwell, Oxford, pp. 173-189.

Birks, H.H., 2001. Plant macrofossils. In: Smol, J.P., Birks, H.J.B., Last, W.M. (Eds.), 2001. Tracking Environmental Change Using Lake Sediments, vol. 3. Kluwer, Dordrecht, pp. 49-74.

Birks, H.H., 2007. Plant macrofossil introduction. In: Elias, S.A. (Ed.), 2007. Encyclopedia of Quaternary Science, vol. 3. Elsevier, Amsterdam, pp. 2266-2288.

Birks, H.H., Birks, H.J.B., 2000. Future uses of pollen analysis must include plant macrofossils. Journal of Biogeography 27, 31-35.

Birks, H.H., Birks, H.J.B., 2006. Multiproxy studies in palaeolimnology. Vegetation History and Archaeobotany 15, 235-251.

Birks, H.H., Battarbee, R.W., Birks, H.J.B., 2000. The development of the aquatic ecosystem at Kråkenes Lake during the late-glacial and early-Holocene a synthesis. Journal of Paleolimnology 23, 91-114.

Birks, H.J.B., Heiri, O., Seppa, H., Bjune, A.E., 2010. Strengths and weaknesses of quantitative climate reconstructions based on late-Quaternary biological proxies. The Open Ecology Journal 3, 68-110.

Butler, K., Prior, C.A., Flenley, J.R., 2004. Anomalous radiocarbon dates from Easter Island. Radiocarbon 46, 395-405.

Cohen, A.S., 2003. Paleolimnology. Oxford University Press, New York.

Danzeglocke, U., Jöris, O., Weninger, B., 2008. CalPal-2007 Online. http://www. calpal-online.de (accessed 18.10.11.).

Dieffenbacher-Krall, A., 2007. Surface samples, taphonomy, representation. In: Elias, S.A. (Ed.), Encyclopedia of Quaternary Science. Elsevier, Amsterdam, pp. 2367-2374.

Dumont, H.J., Cocquyt, C., Fontugne, M., Arnold, M., Reyss, J.-L., Bloemendal, J., Oldfield, F., Steenbergen, C.L.M., Korthals, H.J., Zeeb, B.A., 1998. The end of moai quarrying and its effect on Rano Raraku, Easter Island. Journal of Paleolimnology $20,409-422$.

Etienne, M., Michea, G., Díaz, E., 1982. Flora, vegetación y potencial pastoral de la Isla de Pascua. Boletín Técnico n ${ }^{\circ}$ 47. Facultad de Ciencias Agrarias, Veterinarias y Forestales. Universidad de Chile, Santiago de Chile.

Flenley, J.R., 1993. The palaeoecology of Easter Island, and its ecological disaster. In: Fischer, S.R. (Ed.), Easter Island Studies: Contribution to the History of Rapanui in Memory of William T. Mulloy. The Short Run Press, Oxbow, Oxford, pp. $27-45$.

Flenley, J.R., Bahn, P., 2003. The Enigmas of Easter Island. Island on the Edge. Oxford University Press.

Flenley, J.R., King, S.M., 1984. Late Quaternary pollen records from Easter Island. Nature 307, 47-50.

Flenley, J.R., King, S.M., Jackson, J., Chew, C., Teller, J.T., Prentice, M.E., 1991. The late Quaternary vegetational and climatic history of Easter Island. Journal of Quaternary Science 6, 85-115.

Fritz, S.C., 2008. Deciphering climatic history from lake sediments. Journal of Paleolimnology 39, 5-16.

Gauch, H.G., Whittaker, R.H., 1981. Hierarchical classification of community data. Journal of Ecology 69, 537-557.

Geller, G., 1992. The temperature stratification and related characteristics of Chilean lakes in midsummer. Aquatic Sciences 54, 37-57.

Giralt, S., Moreno, A., Bao, R., Sáez, A., Prego, R., Valero-Garcés, B., Pueyo, J.J. González-Samperiz, P., Taberner, C., 2008. A statistical approach to disentangle environmental forcings in a lacustrine record: the Lago Chungará case (Chilean Altiplano). Journal of Paleolimnology 40, 195-215.

González-Ferran, O., Mazzuoli, R., Lahsen, A., 2004. In: Centro de Estudios Volcánologicos (Ed.), Geología del Complejo Volcánico Isla de Pascua Rapa Nui Santiago-Chile 1:30.000 Geol. map. 
Greenwood, D.R., 1991. The taphonomy of plant macrofossils. In: Donovan, S.K. (Ed.), The Processes of Fossilization. Belhaven Press, London, pp. 141-169.

Grimm, E.C., Donovan, J.J., Brown, K.J., 2011. A high-resolution record of climate variability and landscape response from Kettle Lake, northern Great Plains, North America. Quaternary Science Reviews 30, 2626-2650.

Herrera, C., Custodio, E., 2008. Conceptual hydrogeological model of volcanic Easter Island (Chile) after chemical and isotopic surveys. Hydrogeology Journal 16, 1329-1348.

Hill, M.O., 1979. TWINSPAN - A FORTRAN Program for Arranging Multivariate Data in an Ordered Two-way Table by Classification of Individuals and Attributes. Cornell University, Ithaca, New York, USA.

Horrocks, M., Wozniak, J.A., 2008. Plant microfossil analysis reveals disturbed forest and mixed-crop, dryland production system at Te Niu, Easter Island. Journal of Archaeological Science 35, 126-142.

Hunter-Anderson, R., 1998. Human vs. climatic impacts: did the Rapanui really cut down all those trees? In: Stevenson, C., Lee, G., Morin, F.J. (Eds.), Easter Island in Pacific Context: South Seas Symposium. Proceedings of the Fourth International Conference on Easter Island and East Polynesia. Easter Island Foundation, pp. 85-99.

Janssen, C.R., Birks, H.J.B., 1994. Recurrent groups of pollen types in time. Review of Palaeobotany and Palynology 82, 165-173.

Jongman, R.H.G., ter Braak, C.J.F., van Tongeren, O.F.R. (Eds.), 1995. Data Analysis in Communiy and Landscape Ecology. Cambridge University Press.

Juggins, S., 2003. C2 User Guide. Software for Ecological and Palaeoecological Data Analysis and Visualisation. University of Newcastle.

Kaushal, S., Binford, M.W., 1999. Relationship between C: N ratios of lake sediments, organic matter sources, and historical deforestation in Lake Pleasant, Massachusetts, USA. Journal of Paleolimnology 22, 439-442.

Kling, G.W., 2000. A lake's life is not its own. Nature 408, 149-150.

Lotter, A.F., Birks, H.J.B., 2003. The Holocene palaeolimnology of Sägistalsee and its environmental history - a synthesis. Journal of Paleolimnology 30 , 333-342.

Mann, D., Edwards, J., Chase, J., Beck, W., Reanier, R., Mass, M., Finney, B., Loret, J., 2008. Drought, vegetation change, and human history on Rapa Nui (Isla de Pascua, Easter Island). Quaternary Research 69, 201-206.

Meyers, P.A., 1994. Preservation of elemental and isotopic source identification of sedimentary organic matter. Chemical Geology 114, 289-302.

Nunn, P.D., 2000. Environmental catastrophe in the Pacific Islands around A.D. 1300. Geoarchaeology 15, 715-740.

Ogawa, N.O., Koitabashi, T., Oda, H., Nakamura, T., Ohkouchi, N., Wada, E., 2001. Fluctuations of nitrogen isotope ratio of gobiid fish (Isaza) specimens and sediments in Lake Biwa, Japan, during the 20th century. Limnology and Oceanography 46, 1228-1236.

O’Reilly, C.M., Dettman, D.L., Cohen, A.S., 2005. Paleolimnological investigations of anthropogenic environmental change in Lake Tanganyika: VI. Geochemical indicators. Journal of Paleolimnology 34, 85-91.

Orliac, C., 2000. The woody vegetation of Easter Island between the early 14 th and the mid-17th centuries AD. Easter Island archaeology. In: Stevenson, C.M. Ayres, W.S. (Eds.), Research on Early Rapanui Culture. Easter Island Foundation, Los Osos, pp. 211-220.
Orliac, C., Orliac, M., 1998. The disappearance of Easter Island's forest: overexploitation or climatic catastrophe? In: Stevenson, C., Lee, G., Morin, F.J. (Eds.), Easter Island in Pacific Context: South Seas Symposium. Proceedings of the Fourth International Conference on Easter Island and East Polynesia. Easter Island Foundation, Los Osos, pp. 129-134.

Peteet, D., Beck, W., Ortiz, J., O’Connell, S., Kurdyla, D., Mann, D., 2003. Rapid vegetational and sediment change from Rano Aroi crater, Easter Island. In: Loret, J., Tanacredi, J.T. (Eds.), Scientific Exploration into the World's Environmental Problems in Microcosm. Kluwer Academic/Plenum Publ., New York, pp. 81-92.

R Development Core Team, 2008. R: A Language and Environment for Statistica Computing. R Foundation for Statistical Computing, Vienna, Austria. http:// www.R-project.org/.

Reimer, P.J., Baillie, M.G.L., Bard, E., Bayliss, A., Beck, J.W., Blackwell, P.G. Ramsey, C.B., Buck, C.E., Burr, G.S., Edwards, R.L., Friedrich, M., Grootes, P.M., Guilderson, T.P., Hajdas, I., Heaton, T.J., Hogg, A.G., Hughen, K.A., Kaiser, K.F. Kromer, B., McCormac, F.G., Manning, S.W., Reimer, R.W., Richards, D.A. Southon, J.R., Talamo, S., Turney, C.S.M., van der Plicht, J., Weyhenmeyer, C.E., 2009. IntCal09 and Marine09 radiocarbon age calibration curves, $0-50,000$ years cal BP. Radiocarbon $51,1111-1150$.

Rubensdotter, L., Rosqvist, G., 2003. The effect of geomorphological setting on Holocene lake sediment variability, northern Swedish Lapland. Journal of Quaternary Science 18, 757-767.

Rull, V., Cañellas-Boltà, N., Sáez, A., Giralt, S., Pla, S., Margalef, O., 2010. Paleoecology of Easter Island: evidence and uncertainties. Earth-Science Reviews 99, 50-60.

Sáez, A., Cabrera, L., 2002. Sedimentological and palaeohydrological responses to tectonics and climate in a small, closed, lacustrine system: Oligocene As Pontes Basin (Spain). Sedimentology 49, 1073-1094.

Sáez, A., Valero-Garcés, B., Giralt, S., Moreno, A., Bao, R., Pueyo, J.J., Hernández, A. Casas, D., 2009. Glacial to Holocene climate changes in the SE Pacific. The Raraku Lake sedimentary record (Easter Island, $27^{\circ} \mathrm{S}$ ). Quaternary Science Reviews 28, 2743-2759.

Scheihing, M.H., Pfefferkorn, H.W., 1984. The taphonomy of land plants in the Orinoco Delta: a model for the incorporation of plant parts in clastic sediments of Late Carboniferous age of Euramerica. Review of Palaeobotany and Palynology 41, 205-240.

Skottsberg, C. (Ed.), 1956. The Natural History of Juan Fernández and Easter Island. Almquist \& Wiksells, Uppsala.

Smol, J., Glew, J., 1992. Paleolimnology. In: Nierenberg, W.A. (Ed.), 1992. Encyclopedia of Earth System Science, vol. 3. Academic Press, San Diego, pp. 551-564

Ter Braak, C.J.F., 1986. Interpreting a hierarchical classification with simple discriminant functions: an ecological example. In: Diday, E. (Ed.), 1986. Data Analysis and Informatics, vol. 4, pp. 11-21. North Holland, Amsterdam.

Tschudy, R.H., 1969. Relation of Palynomorphs to sedimentation. In: Tschudy, R.H., Scott, R.A. (Eds.), Aspects of Palynology. Wiley-Interscience, New York, pp. 79-96.

Zhao, Y., Sayer, C.D., Birks, H.H., Hughes, M., Peglar, S.M., 2006. Spatial representation of aquatic vegetation by macrofossils and pollen in a small and shallow lake. Journal of Paleolimnology 35, 335-350.

Zizka, G., 1991. Flowering plants of Easter Island. Palmarum Hortus Francofurtensis Scientific Reports, pp. 1-108. 